2011

\title{
The Ethics of Willful Ignorance
}

Rebecca Roiphe

New York Law School, rebecca.roiphe@nyls.edu

Follow this and additional works at: http://digitalcommons.nyls.edu/fac_articles_chapters

Part of the Legal Ethics and Professional Responsibility Commons

\section{Recommended Citation}

Georgetown Journal of Legal Ethics, Vol. 24, Issue 1 (Winter 2011), pp. 187-224

This Article is brought to you for free and open access by the Faculty Scholarship at DigitalCommons@NYLS. It has been accepted for inclusion in Articles \& Chapters by an authorized administrator of DigitalCommons@NYLS. 


\title{
The Ethics of Willful Ignorance
}

\author{
REBECCA ROIPHE*
}

In general, courts, legislatures, and regulators do not excuse individuals, including lawyers, from legal obligations because they turned a blind eye to the underlying facts. By defining knowledge as "actual knowledge," the ABA's Model Rules of Professional Conduct, however, allow lawyers to avoid responsibilities to the community and the public by remaining ignorant of relevant facts. For example, lawyers do not face disciplinary charges for assisting in client fraud as long as they avoid information that might lead them to know about the criminal conduct. David Luban, one of the leading scholars in the field, has defended the ABA's approach, arguing that lawyers must be allowed to avoid the truth to protect the lawyer-client relationship. This Article questions Luban's thesis. Tolerating willful ignorance not only undermines the rules that protect the public, but also conflicts with the premises of the attorney-client relationship. By defining knowledge as actual knowledge, the ethical rules promote duties to the public on the surface while allowing lawyers to ignore them in reality, which reinforces a sense that the responsibility to the community and the rules designed to enforce it are merely ornamental. Furthermore, this definition of knowledge undermines the efficacy of the attorney-client relationship by subtly promoting a failure of communication and aborted investigations. As embodied in the rules of confidentiality and privilege, the lawyer's access to all relevant information is necessary to represent the client well. The tacit approval of willful ignorance conflicts with such informed representation. This Article argues that the Model Rules ought to require all lawyers to pursue important and obvious facts and directly address the proper balance between the lawyers' loyalty to the client and obligation to the public with regard to the substantive rules in the context of different areas of practice.

\section{TABLE OF CONTENTS}

INTRODUCTION . . . . . . . . . . . . . . .

I. BACKGROUND $\ldots \ldots \ldots \ldots \ldots \ldots \ldots \ldots \ldots \ldots$

* Associate Professor of Law, New York Law School. Ph.D., University of Chicago (2002); J.D., Harvard Law School (2000). I would like to thank the participants of the first "Ethics Schmooze," organized by Fordham Law School, Stanford Law School, Georgetown University Law Center, and Columbia Law School, for their invaluable comments on an earlier draft. I would especially like to thank David Luban for his willingness to engage dissent. In addition, Elise Boddie, Elizabeth Chambliss, Doni Gewirtzman, Bruce Green, James Grimmelmann, Benjamin Gruenstein, Molly Land, Tanina Rostain, Houman Shadab, and Faith Stevelman have offered their valuable insight. (C) 2010, Rebecca Roiphe. 
A. WILLFUL IGNORANCE IN CRIMINAL LAW . . . . . . . . . 192

B. WILLFUL IGNORANCE AND ETHICAL STANDARDS . . . . 196

1. The Meaning of the Actual Knowledge Standard . . . . . 196

2. The Bar's Efforts at Self-Regulation. . . . . . . . . . . 199

II. Professor Luban's ARgument AND THE IMPACT ON THE Attorney-Client Relationship. . . . . . . . . . . . . 202

III. Attorney Liability In CRiminal, Civil, AND SEC

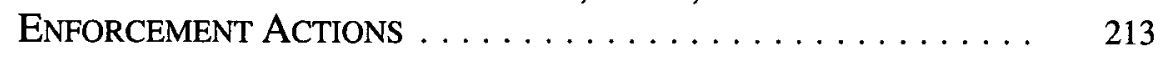

A. CRiminal law ..................... 213

B. CIVIL LIABILITY FOR SECURITIES FRAUD . . . . . . . 215

C. NEGLIGENCE AND MALPRACTICE. ............ 216

D. REGULATORY SANCTIONS ............... 217

IV. Resolving Conflict Between Bodies Regulating

Lawyer Conduct . . . . . . . . . . . . . . . . . 218

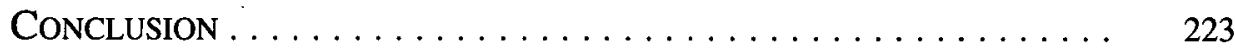

\section{INTRODUCTION}

In the wake of the recent financial crisis, scholars have asked whether lawyers might have played a more active role in preventing the collapse. ${ }^{1}$ They have revisited with a new urgency the question of whether lawyers ought to serve as gatekeepers, monitoring the legality of their clients' actions. ${ }^{2}$ One issue central to this recurrent concern is whether we should excuse lawyers for ignoring suspicious facts that would trigger either reporting obligations or the need for

1. See Steven L. Schwarcz, Keynote Address: The Role of Lawyers in the Global Financial Crisis, 24 AusTL. J. CoRP. L. (forthcoming. 2010), available at http://papers.ssm.com/sol3/papers.cfm?abstract_id=1532794 (hereinafter Keynote Address); Steven L. Schwarcz, The Public Responsibility of Structured Finance Lawyers, 1 CAP. Markets L. J. 6 (2006); Andreas Bohrer, The Impact of the Financial Crisis on the Law and the Legal Profession (2009 Int'l Junior Faculty Forum, Harvard Law Sch. \& Stanford Law Sch., 2009), available at http://ssrn.com/abstract $=1511323$.

2. See sources cited supra note 1. The literature on lawyers' role as gatekeepers is enormous. See, e.g., John C. Coffee, Jr., Gatekeeper Failure and Reform: The Challenges of Fashioning Relevant Reforms, 84 B.U. L. REv. 301 (2004); Howell E. Jackson, Reflections on Kaye, Scholer: Enlisting Lawyers to Improve the Regulation of Financial Institutions, 66 S. CAL. L. REv. 1019 (1993); Reinier H. Kraakman, Gatekeepers: The Anatomy of a Third-Party Strategy, 2 J. L. ECON. \& ORG. 53 (1986). 
further investigation. ${ }^{3}$

Like most corporate scandals, the now infamous story of Enron's demise has, among other things, the character of the attorney who facilitates the wrongdoing, in part, by remaining ignorant of its most grisly aspect. Sherron Watkins, a vice president for corporate development at Enron, warned chairman Kenneth Lay that the company was engaged in a series of accounting frauds so severe that the entire enterprise was at risk. Before the collapse, Watkins told Lay that with Arthur Andersen's help, Enron had manufactured investment deals designed to keep massive amounts of debt off the books and falsely inflate the company's earnings. Lay engaged the law firm Vinson \& Elkins, which had been involved in the underlying transactions, to review the limited partnership deals but specifically instructed the attorneys not to look into Arthur Andersen's treatment of them. The law firm reported back that the transactions looked fine because the accountants had signed off on them. Lawyers from Vinson \& Elkins interviewed seven senior executives, who were themselves implicated in Watkins' allegations, and did not interview any of the lower level employees who had been identified as potential witnesses to the problem. With blinders on, the attorneys continued on course. ${ }^{4}$

Much has been written on the notion of "conscious avoidance," or "willful ignorance" in criminal law. ${ }^{5}$ In essence, the criminal law doctrine dictates that someone who deliberately ignores obvious facts is as culpable as a person who knows those facts but continues despite them. ${ }^{6}$ Most courts and regulators adhere

3. Schwarcz, Keynote Address, supra note 1, at 11-13.

4. Roger C. Crampton, Enron and the Corporate Lawyer: A Primer on Legal and Ethical Issues, 58 Bus. LAW. 143, 162-64 (2002); Robert W. Gordon, A New Role for Lawyers: The Corporate Counselor After Enron, 35 ConN. L. REv. 1185, 187-88 (2003); Milton C. Regan, Teaching Enron, 74 FordHAM L. Rev. 1139, 1230-32 (2005); William H. Simon, Wrongs of Ignorance and Ambiguity: Lawyer Responsibility for Collective Misconduct, 22 YALE J. ON REG. 1, 5-8 (2005). David Luban uses an earlier example: In the OPM case, a law firm represented a client who was defrauding the bank of billions of dollars. When presented with a letter containing information about the fraud from the client's accountant, the lawyer asked the accountant to take the letter back before he had read it. DAvid LUBAN, Legal ETHICS AND HuMAN DiGNITY 209 (2007).

5. Like most of the literature, this Article uses the terms "conscious avoidance" and "willful ignorance" interchangeably.

6. The pattern jury instruction reads as follows:

In determining whether the defendant acted knowingly, you may consider whether the defendant deliberately closed his eyes to what would otherwise have been obvious to him. If you find beyond a reasonable doubt that the defendant acted with . . . a conscious purpose to avoid learning the truth ... then this element may be satisfied. However, guilty knowledge may not be established by demonstrating that the defendant was merely negligent, foolish or mistaken .... If you find that the defendant was aware of a high probability that (e.g., the statement was false) and that the defendant acted with deliberate disregard of the facts, you may find that the defendant acted knowingly. However, if you find that the defendant actually believed that (e.g., the statement was true), he may not be convicted. It is entirely up to you whether you find that the defendant deliberately closed his eyes and any inferences to be drawn from the evidence on this issue.

MOdern Federal Jury InSTRUCtIONS-CRIMINAL § 3A-5. 
to some version of the same standard in civil securities fraud cases as well. ${ }^{7}$ Thus, courts and regulators do not allow individuals-including lawyers-to ignore obvious facts when doing so would make them participants in criminal conduct. The ethical rules, however, hold lawyers to a lower standard. Under the current rules, a lawyer acts knowingly when he has "actual knowledge of the fact in question." The Model Rules qualify that "knowledge may be inferred from the circumstances." ${ }^{8}$ Deliberately turning a blind eye to relevant facts, however, would not meet the mens rea requirement under this standard.

Professor David Luban, a preeminent professional ethics scholar, defends the bar's position with regard to willful ignorance by emphasizing how crucial this game of denial is to the integrity of the attorney-client relationship. According to Luban, clients would grow to distrust lawyers if they pursued information harmful to the clients' interest. ${ }^{9}$ This argument overlooks the bar's own conviction, embraced in the ethical rules and elsewhere, that communication, knowledge, and truthfulness are the cornerstone of a productive attorney-client relationship. ${ }^{10}$ By condoning willful ignorance, the bar cannot possibly preserve the sanctity of the attorney-client relationship because it simultaneously undermines communication, which, in other contexts, it has proclaimed to be the essence of that relationship.

Lawyer-philosophers have spent many pages considering the value of the willful ignorance doctrine. Is it fair to punish someone who didn't know what he was doing, even if his ignorance was a product of his own mental gymnastics? Isn't this the same as punishing a person for what he should have known-a negligence standard generally inapplicable in criminal law? Perhaps, the Model Penal Code explains, we should simply assert that someone who is aware of the high probability of a fact is deemed to know that fact. ${ }^{11}$ Despite disagreement about the exact form of the test and when it ought to be triggered, the criminal courts have generally applied some version of the willful ignorance standard. The bar, however, has remained fairly consistent in its refusal to acknowledge conscious avoidance as a state of mind that triggers ethical obligations. ${ }^{12}$

7. See infra Part III.B.

8. Model Rules of Prof'L Conduct R. 1.0(f) (2010) [hereinafter Model Rules].

9. See David Luban, Contrived Ignorance, 87 GEo. L. J. 957, 976-80 (1999).

10. Model Rules R. 1.6; ABa Presidential Task Force on the Attorney-Client Privilege, Report to THE HouSE OF DELEGATES (June 7, 2005), available at www.abanet.org/buslaw/attorneyclient/materials/hod/ report.pdf.

11. Luban, supra note 9, at 959-62; Douglas N. Husak \& Craig A. Callender, Willful Ignorance, Knowledge, and the "Equal Culpability" Thesis: A Study of the Deeper Significance of the Principle of Legality, 1994 WISC. L. Rev. 29, 36 (1994); Robin Charlow, Willful Ignorance and Criminal Culpability, 70 TEx. L. REv. 1351, 1367-68 (1991); see also Stephen Ellmann, Truth and Consequences, 69 FordHAM L. REV. 895 (2000) (discussing willful ignorance, the confidentiality rules, and the rules forbidding a lawyer from presenting false testimony in the context of a client interview).

12. Part I of this Article reviews and assesses some of the tests for willful ignorance that have made their way into the criminal law but remains, for the most part, agnostic about the exact formulation of the test that ought to 
This Article argues that by doing so, the bar has muffled a debate about the proper balance between the public role of lawyers and their duties to clients. This is a debate which, given the increasingly diverse profession, ought to take account of the different work that lawyers do. The actual knowledge requirement manufactures a semblance of uniformity in legal regulation, masking the truly contextual nature of legal ethics. ${ }^{13}$ For instance, it allows for one rule against perjured testimony when most everyone knows that criminal defense lawyers and civil litigators treat this rule differently. ${ }^{14}$ Forbidding lawyers from avoiding ethical obligations by turning a blind eye to obvious facts would force this conversation about the obligations of lawyers to their clients and the public to the surface. It would in turn require the profession to examine how this balance might tip depending on the different practice areas and clients that lawyers represent.

Part I of this Article provides background on the notion of willful ignorance in criminal law. It explores the literature on the doctrine of willful ignorance as a criminal mens rea requirement and analyzes how these debates map onto professional ethics. Because federal criminal law and the law of most states condemn an individual who willfully avoids obvious and relevant facts, this section concludes that it makes no sense for ethical rules to treat lawyers with greater leniency.

Part II addresses Professor Luban's arguments supporting the bar's current definition of knowledge and shows that they are either illogical or based on unlikely empirical assumptions. By focusing disproportionately on criminal defense attorneys, Luban takes insufficient account of the context in which different lawyers operate. Like the bar, he approves of the willful ignorance standard because it creates the illusion that all lawyers follow the substantive ethical requirements equally. In reality, by turning a blind eye to their client's guilt, most criminal defense attorneys use the actual knowledge standard to abide by the perjury rules in a superficial and formalistic way at best.

Part III demonstrates that in the context of assisting in client fraud, courts, legislatures, and regulatory bodies have far higher expectations of lawyers than the bar, proscribing deliberate blindness to client wrongdoing. This section demonstrates that by clinging to the actual knowledge standard, the bar is embracing a particular balance between lawyers' obligations to their clients (or constituents of their clients) and the public. Rather than doing so in a transparent

be applied to professional ethics. The precise wording of the rule and application of the test would obviously have to be worked out if the ABA or state courts were to integrate willful ignorance into the mens rea definitions.

13. In making this point throughout this Article, I am indebted to the path breaking insights of Professor David Wilkins. David B. Wilkins, Making Context Count: Regulating Lawyers After Kaye, Scholer, 66 S. CAL. L. REv. 1145, 1152-53 (1993).

14. See Model Rules R. 3.3. Criminal defense lawyers are usually quite liberal in allowing their clients to testify, even when the testimony is fairly obviously false. Civil litigators are generally more scrupulous, preventing witnesses from introducing false evidence. This makes some sense given that criminal defendants have a right to testify on their own behalf while civil litigants have no such right. 
way, however, the actual knowledge standard obscures the fact that the bar has opted for a client-centered approach, making it seem as if lawyers are equally concerned with the effect of their actions on the public. This Part of the Article also highlights the obvious fact that government regulators are increasingly targeting lawyers by practice area. In what seems a stubborn commitment to a uniform bar, the ABA resists the sorts of distinctions between practicing lawyers that are becoming increasingly significant in the regulatory world. By doing so, this section argues, the bar is at risk of rendering itself obsolete. If it proves unable to keep pace with the changes in the profession and the regulatory world, the professional bar might lose its position of influence.

Part IV draws on this discussion to argue that in this context, the bar ought to embrace a role consistent with the expectations of other regulatory bodies. In doing so, it concludes that the debate over which body ought to regulate lawyers is, in fact, a debate over the role of lawyers in the democratic system. By allowing lawyers to blind themselves to obvious facts, the current ethics code embraces a uniformly client-centered approach to lawyering while maintaining a cosmetic commitment to the public and the legal system as a whole. In addition to bringing the debate to the surface, adopting a willful ignorance standard will encourage the bar to examine whether this client-centered approach is appropriate in all practice areas or only in certain contexts.

\section{BACKGROUND}

\section{A. WILLFUL IGNORANCE IN CRIMINAL LAW}

Academics have long debated the wisdom of the willful ignorance standard in criminal law. Despite the theoretical controversy, most courts apply some version of this standard in holding individuals and entities criminally liable. Both the history of the standard and the scholarly debate support the conclusion that the ethical rules ought to include a willful ignorance standard.

Willful blindness, known at the time as connivance, first surfaced in the mid-nineteenth century in England. In 1861, a judge in Regina v. Sleep ruled that the defendant could not be guilty of possessing "naval stores" unless there was proof that he either knew that the goods were government-owned or "willfully shut his eyes to the fact." 15 This arguably indirect acknowledgment of the willful ignorance doctrine was followed fourteen years later by a British court, which explicitly relied on the concept in upholding a conviction of an innkeeper for knowingly permitting gambling on the premises. ${ }^{16}$ The gamblers had corroborated the innkeeper's story that she had no knowledge of what they were doing.

15. 169 REv. REP. 1296, 1302-03 (Q.B. 1861). For a more detailed discussion of the origins of deliberate ignorance, see J. Edwards, The Criminal Degrees of Knowledge, 17 MoD. L. REv. 294, 297-300 (1954).

16. See Bosley v. Davies, 1 Q.B.D. 84, 85-88 (1875). 
The court upheld the conviction nonetheless, reasoning that "actual knowledge in the sense of seeing or hearing by the party charged is not necessary, but there must be some circumstances from which it may be inferred that he or his servants had connived at what was going on."17

In America at the turn of the nineteenth century, courts invoked the notion of willful ignorance most frequently in the context of regulatory crimes. For instance, the court in People v. Glennon reversed the conviction of an officer for failing to restrain a house of prostitution. The court remanded, directing that the jury ought to be instructed that the officer could be culpable under the statute if he knew that it was a brothel or if he failed to investigate clear evidence that the premises were being used for such illicit purposes. ${ }^{18}$ Professor Robin Charlow has argued that, as in Glennon, the early American cases tended to equate willful ignorance with knowledge when there was an independent statutory obligation to know. ${ }^{19}$ Thus it seems likely that the growing web of regulation and the accompanying obligations placed on private citizens in the late nineteenth century provoked a perceived need to expand the definition of knowledge. In other words, as the regulatory state grew to rely on private citizens' obligations to each other and the community, the criminal law gradually began to punish individuals for deliberately ignoring facts that would clearly trigger such obligations. ${ }^{20}$

The federal courts similarly adopted the willful ignorance standard in the beginning of the twentieth century. In 1899, the Supreme Court tacitly approved the notion in Spurr v. United States. ${ }^{21}$ The defendant in Spurr, a bank officer, had been convicted of certifying a check when he knew the drawer lacked sufficient funds in the account. On appeal, the Court noted that "evil design can be presumed if the officer purposely keeps himself in ignorance of whether the drawer has money in the bank or not." ${ }^{\text {22 }}$ While the issue of jury instructions was not before the Court, the Court did acknowledge the propriety of willful ignorance as a substitute for the statutory mens rea requirement.

The deliberate ignorance standard gained momentum in the 1970s with the increase in narcotics prosecutions. ${ }^{23}$ In United States $v$. Jewell, the leading federal case involving willful ignorance, Jewell was convicted of importing

\footnotetext{
17. Id. at 88 .

18. People v. Glennon, 67 N.E. $125,128-29$ (N.Y. 1903).

19. Charlow, supra note 11 , at 1406-07.

20. For a discussion of the emergence of the regulatory state and the changes in the law and culture, see generally Steven Skowronek, Bullding a New american State: The Expansion of National AdministraTIVE CAPACITIES, 1877-1920 (1982); ROBERT H. WIEBE, THE SEARCH FOR ORDER: 1877-1920 (1967); RICHARD HofSTADTER, THE AGE OF REFORM: FROM BRYAN TO F.D.R. (1955).

21. See Spurr v. United States, 174 U.S. 728, 734-39 (1899).

22. Id. at 735 .

23. Kristen L. Chesnut, Comment, United States v. Alvaredo: Reflections on a Jewell, 19 GoldEN GATE U. L. REv. 47, 49 (1989).
} 
marijuana in a car he was driving from Mexico to the United States. ${ }^{24}$ At trial, he testified that he did not know what was in the car. An agent elaborated that Jewell had admitted that he thought something illegal was likely in the car but that he had checked the glove compartment and found nothing. The Court approved an instruction that directed that the jury could convict if it found that the defendant was unaware of the contraband in the car as long as his ignorance "in that regard was solely and entirely a result of his having made a conscious purpose to disregard that which was in the vehicle." 25 Federal courts have subsequently formulated the test slightly differently and disagreed over how readily judges ought to issue the conscious avoidance jury instruction, but they have universally adopted some version of the doctrine. ${ }^{26}$

Scholars of criminal law have long debated the wisdom of holding individuals criminally liable on evidence that they deliberately ignored relevant facts. Some note that willful ignorance implies the lack of knowledge. As a result, willful ignorance and knowledge cannot possibly be the same thing, and a court acts illegitimately or even unconstitutionally by reading such an opposing term into the meaning of knowledge. ${ }^{27}$ Others voice the concern that while willful blindness is not exactly a negligence standard-punishing someone when that person should have known about certain facts-juries will invariably elide the two. Negligence implies a duty to know. Certain relationships can impose this duty in certain circumstances but it defies common sense to assume that everyone has a duty to know everything at all times such that the deliberate evasion of facts is culpable. ${ }^{28}$ Thus, even though we do not normally consider negligence a sufficient state of mind for criminal prosecution, individuals will be convicted for a negligent failure to investigate. ${ }^{29}$

The Model Penal Code offers an antidote to these criticisms, phrasing the test as an affirmative mental state rather than the absence of knowledge. ${ }^{30}$ In other words, the Model Penal Code equates being aware of the high probability of a fact with knowledge. ${ }^{31}$ But, as critics have recognized, the Model Code formulation does not really approach the same problem as willful ignorance. Instead, it imposes a lesser mental state somewhat akin to recklessness. ${ }^{32}$ Rather

24. United States v. Jewell, 532 U.S. 697, 698 (en banc), cert. denied, 426 U.S. 951 (1976).

25. Id. at 700 .

26. Jonathan L. Marcus, Note, Model Penal Code Section 2.02(7) and Willful Blindness, 102 YALE L.J. 2231, 2245-49 (1993).

27. Ira P. Robbins, The Ostrich Instruction: Deliberate Ignorance as a Criminal Mens Rea, $81 \mathrm{~J}$. CRIM. L. AND CRIMINology 191, 194-227 (1990).

28. LUBAN, supra note 4 , at 209-11.

29. Luban, supra note 9 , at 959-60.

30. Charlow, supra note 11, at 1394-96; Robbins, supra note 27, at 223-26.

31. Model Penal CODE $\$ 2.02(7)$ ("When knowledge of the existence of a particular fact is an element of an offense, such knowledge is established if a person is aware of a high probability of its existence, unless he actually believes that it does not exist.").

32. Charlow, supra note 11, at 1394-96; Robbins, supra note 27, at 223-26. 
than focus on how deliberate the individual was in avoiding knowledge, the Model Code simply demotes the requisite mens rea requirement to something short of actual knowledge. ${ }^{33}$

Among the critics of willful ignorance are those who accept the common sense of some version of the doctrine but argue that the standard ought better suit the conduct we deem morally culpable. ${ }^{34}$ For instance, Professor Holly Smith suggests that the law should focus entirely on how deliberate the individual was in setting up the screening mechanism to avoid the requisite knowledge. In other words, courts should focus on the individual's state of mind at the time she shielded herself from the guilty knowledge rather than her state of mind at the time of the misdeed. ${ }^{35}$ David Luban borrows from Smith's approach but ultimately departs from her conclusion, suggesting that the jury should look at the individual's state of mind regarding the misdeed - rather than the defense against knowledge of the misdeed - at the time that individual chose to shield herself from guilty knowledge. ${ }^{36}$ In other words, Luban argues, if an individual wishes to commit a crime and hides from reality simply as a means to avoid liability, that person ought to be held responsible. If, on the other hand, the individual would not have committed the crime if she had allowed herself to acknowledge the facts, that person should not be punished. ${ }^{37}$

The courts have all opted for a simpler test-some variant of the Model Penal Code or the Jewell test-perhaps for ease of application. ${ }^{38}$ But there is no reason Smith and Luban's critique could not be integrated into jury instructions or, in the context of legal ethics, the comments following the Model Rules. This commentary seems particularly relevant for charging decisions and the exercises of discretion that accompany them.

33. Charlow, supra note 11, at 1373-96.

34. See Charlow, supra note 11, at 1413-18 (arguing that willful ignorance should be viewed as a culpable mental state when an individual deliberately blinds himself to certain facts in order to avoid criminal punishment); see also Larry Alexander, Insufficient Concern: A Unified Conception of Criminal Culpability, 88 CALIF. L. REv. 931, 932 (2000) (arguing that courts ought to focus on how risky it was for the individual to do what he did); Alan C. Michaels, Acceptance: The Missing Mental State, 71 S. CAL. L. Rev. 953, 962-63 (1998) (arguing that the individual's indifference to the consequences of his acts should dictate his culpability).

35. See Holly Smith, Culpable Ignorance, 92 PHIL. Rev. 543, 555-71 (1983).

36. Luban, supra note 9, at 973-74. Luban's proposal is similar to Charlow's in that both suggest looking at the individual's state of mind with regard to the criminal act at the time that individual shielded herself from guilty knowledge. In this way, the two scholars depart from both Smith and the Model Penal Code. The Model Penal Code formulation, which equates willful ignorance and knowledge when an individual is aware of a high probability of the existence of the underlying fact, ignores the individual's motives for screening herself from guilty knowledge.

37. Id. at 974-75. For a similar argument, see Kimberly Kessler Ferzan, Opaque Recklessness, 91 J. CRIM. L. \& CRIMTNOLOGY 597, 641-52 (2001) (arguing that willful blindness ought to be a culpable state of mind if the individual would have acted even if he possessed the knowledge to which he willfully blinded himself).

38. See generally Marcus, supra note 26. 


\section{B. WILLFUL IGNORANCE AND ETHICAL STANDARDS}

\section{The Meaning of the Actual Knowledge Standard}

The Model Rules of Professional Conduct, like the criminal statutory scheme, frequently authorize discipline when a lawyer knowingly engages in certain unethical conduct. For instance, lawyers must not knowingly assist in a crime or fraud. ${ }^{39}$ Lawyers must not knowingly introduce false testimony in court. ${ }^{40}$ Lawyers for an organization must report up the ladder when they know that an individual within that entity has committed a crime or fraud that could harm the institution. In each of these situations, the lawyer may have an incentive to avoid the knowledge that would require him to act against the wishes of his client (or in the last example, some constituent of his client). The Rules, however, define knowledge as "actual knowledge of the fact in question." 41 By defining knowledge as actual knowledge, the Model Rules contribute to this incentive by allowing lawyers to turn a blind eye to facts that might trigger these difficult obligations designed to protect the public or the integrity of the legal system. The ABA's various interpretations of knowledge in different contexts also illustrate that the bar is using the mens rea requirement subtly to allow for distinctions between the responsibilities of different sorts of lawyers engaged in different sorts of law practice without drawing attention to the disparate treatment under the rules.

After defining knowledge as "actual knowledge," the Model Rules of Professional Conduct do note that "[a] person's knowledge may be inferred from circumstances." ${ }^{42}$ There are several different ways to interpret this phrase. The most reasonable, it seems, is that it prescribes an objective standard of proof but does not change the substantive rule. Thus, the clarification serves as an admonition to lawyers that a finder-of-fact could ignore a lawyer's subjective protestations of ignorance if circumstances belie that claim. For instance, under the Model Rules standard, a lawyer could not hide by insisting that he did not know that his client was committing a crime if it were obvious from e-mails he received or documents he reviewed that he actually knew about the unlawful acts. However, the lawyer would have a successful defense if he did in fact remain ignorant because he never read certain documents or opened certain e-mails because he suspected that they might contain evidence of a crime.

An alternate- and less persuasive-way to understand this provision is that it incorporates willful ignorance into the definition of knowledge. In the context of the "no-contact" rule, the ABA has, in a somewhat confused iteration, interpreted

39. MODEL Rules R. 1.2(d).

40. MOdel Rules R. 3.3(a).

41. Model Rules R. 1.0(f).

42. Id. In the context of client perjury, the Restatement uses a similar definition of knowledge. See RESTATEMENT (THIRD) OF THE LAW GOVERNING LAWYERS $§ 120 \mathrm{cmt} . \mathrm{c}$ (2000). 
knowledge to include some version of deliberate ignorance. Rule 4.2 provides that, in representing a client, a lawyer "shall not communicate about the subject of the representation with a person the lawyer knows to be represented by another lawyer in the matter." ${ }^{, 3}$ In explaining the scope of this rule, an ABA ethics opinion explained the meaning of knowledge:

Rule 4.2 does not ... imply a duty to inquire. Nonetheless, it bears emphasis that, as stated in the definition of 'knows' . . actual knowledge may be inferred from the circumstances. It follows, therefore, that a lawyer may not avoid Rule 4.2's bar against communication with a represented person simply by closing her eyes to the obvious. ${ }^{44}$

The final inference, which seems to assume the willful ignorance standard, does not quite follow. The fact that actual knowledge can be inferred from the circumstances is a standard of proof. Actual knowledge is still the substantive requirement. Thus, a lawyer who shields himself from facts that clearly indicate that the other party with whom he speaks was represented by counsel could not be sanctioned under the Model Rules. While it might be hard to convince a jury that the lawyer lacked actual knowledge when most reasonable people would have known, there exists a set of circumstances on the margin, at least, in which a jury could believe that the lawyer, who intentionally avoided obvious facts, lacked the requisite actual knowledge, and therefore ought not to be sanctioned. ${ }^{45}$

In the context of client perjury, the Restatement of the Law Governing Lawyers confirms this interpretation of the definition of knowledge as actual knowledge. The comment to the Restatement explains that a lawyer must have "actual knowledge" and that such knowledge may be inferred from the circumstances. But, the comment further explains, a lawyer's knowledge may not be based on "unknown information, even if a reasonable lawyer would have discovered it through inquiry." In order to "know" that testimony is false, the defense lawyer will have to know of facts that contradict his client's story or the client will have to inform him directly that the testimony is false. ${ }^{46}$

Faced with the ambiguity in the language of the Model Rules, some scholars and courts have interpreted the Model Rules to hold lawyers responsible when they deliberately ignore relevant facts. For instance, Professor Charles Wolfram writes:

For the most part, a lawyer is not under an obligation to seek out information. But, as in the criminal law, a lawyer's studied ignorance of a readily

43. Model RuLes R. 4.2 .

44. ABA Comm. on Ethics \& Prof'l Responsibility, Formal Op. $95-396$ (1995).

45. See RESTATEMENT (ThIRD) OF THE LAW GovERNING LAWYERS $\S 5 \mathrm{cmt}$. d (2000) (explaining knowledge as actual knowledge but noting that a mere denial of knowledge will not suffice since knowledge can be inferred from the circumstances).

46. Id. 
ascertainable fact by consciously avoiding it is the functional equivalent of knowledge of the fact .... As a lawyer, one may not avoid the bright light of a clear fact by averting one's eyes or turning one's back. ${ }^{47}$

A Connecticut ethics opinion citing Wolfram similarly reasoned that a lawyer must obtain all the information necessary to provide competent advice to the client. The opinion drew a line very similar to that of the criminal law: Lawyers are entitled to believe their clients insofar as it is reasonable to do so, but "a lawyer may not turn a blind eye to the obvious."48

There is at least some argument that even with the actual knowledge standard, by willfully blinding himself to important facts, a lawyer violates other substantive rules of professional conduct. The rules protecting clients seem to imply some duty to investigate even if the scope of the obligation is vague. ${ }^{49}$ The comments to the rule governing competence provide that "competent handling of a particular matter includes inquiry into and analysis of the factual and legal elements of the problem."50 Arguably, a lawyer cannot comply with his duties of competence and diligence if he turns a blind eye to important facts. Regardless of

47. Charles W. Wolfram, Modern Legal Ethics 696 (1986).

48. Conn. Bar Ass'n Comm. on Prof'1 Ethics, Informal Op. $91-22$ (1991); see also In re Dobson, 427 S.E.2d 166,168 (S.C. 1993) (imposing a two year suspension on a lawyer based in part on the finding that he had "deliberately evaded knowledge of facts which tended to implicate him in a fraudulent scheme"); Office of Disciplinary Counsel v. Anonymous, 714 A.2d 402, 407 (Pa. 1992) ("We hold that a culpable mental state greater than negligence is necessary to establish a prima facie violation of Rule $8.4(\mathrm{c})$. This requirement is met where the misrepresentation is knowingly made, or where it is made with reckless ignorance of the truth or falsity thereof .... [R]ecklessness may be described as the deliberate closing of one's eyes to facts that one had a duty to see or stating as fact, things of which one was ignorant.").

49. Model Rule 1.1 states, "[a] lawyer shall provide competent representation to a client. Competent representation requires the legal knowledge, skill, thoroughness and preparation reasonably necessary for the representation." The comment to Model Rule 1.1 further explains, "[c]ompetent handling of a particular matter includes inquiry into and analysis of the factual and legal elements of the problem, and ... adequate preparation." See also MODEL RULES R. 1.3 ("A lawyer should pursue a matter on behalf of a client despite opposition, obstruction, or personal inconvenience to the lawyer, and take whatever lawful and ethical measures are required to vindicate a client's cause or endeavor. A lawyer must also act with commitment and dedication to the interests of the client and with zeal in advocacy upon the client's behalf."); MODEL RULES R. 3.1 ("A lawyer shall not bring or defend a proceeding, or assert or controvert an issue therein, unless there is a basis in law and fact for doing so that is not frivolous, which includes a good faith argument for an extension, modification or reversal of existing law. A lawyer for the defendant in a criminal proceeding, or the respondent in a proceeding that could result in incarceration, may nevertheless so defend the proceeding as to require that every element of the case be established."). In the criminal context, the ABA standards impose a direct obligation to investigate. ABA Standards for Criminal Justice, Defense Function 4-4.1 (1993) (defense counsel's "duty to investigate exists regardless of the accused's admissions or statements to defense counsel of facts constituting guilt or the accused's stated desire to plead guilty"); see also Wiggins v. Smith, 539 U.S. 510 , 523-37 (2003) (providing more detail on how much investigation is necessary to meet the constitutional minimum and when it is reasonable to forgo investigation); ABA Comm. on Ethics \& Prof'l Responsibility, Formal Op. 335, at 2 ("[A] lawyer should make adequate inquiry into the relevant facts ..., but, while he should not accept as true that which he does not reasonably believe to be true, he does not have the responsibility to 'audit' the affairs of his client, without reasonable cause, that the client's statement of facts cannot be relied on.").

50. Model Rules R. $1.1 \mathrm{cmt} .5$. 
whether willful ignorance would violate the competence rule, it creates an odd and confusing tension to encourage investigation through the substantive standards of attorney conduct while simultaneously discouraging it indirectly through the definition of knowledge. In addition to being an obtuse and potentially confusing way of addressing the problem of lawyers hiding behind claims of ignorance, it allows the bar to project a concern for the public and third parties without requiring lawyers to fulfill that function in reality.

\section{The Bar's Efforts at Self-Regulation}

Reacting to threats of government regulation, the bar has made nods toward a more explicit willful ignorance standard in certain discrete contexts. Rather than demonstrating a genuine response to concerns about lawyer abuse, these efforts depict a professional organ that remains captive of its powerful clients and makes changes only when necessary to satisfy regulators. Given the government's increased interest in monitoring the conduct of professionals, the bar runs the risk of rendering itself obsolete if it does not do more than passively and defensively react during moments of public distrust.

In 1974, for instance, the bar issued an opinion regarding a lawyer's obligation to investigate client representations in writing opinions supporting sales of unregistered securities. ${ }^{51}$ Only certain securities are exempt from registration requirements under the Securities Act of 1933. Companies were using opinion letters from lawyers to claim these exceptions. The ABA instructed that attorneys may rely solely on their clients' representations regarding the securities at issue but must investigate further if there is anything suspicious or conspicuously missing from those representations. ${ }^{52}$ The bar was careful to constrain even this rather modest proposal to the specific context of opinions regarding unregistered securities. Lawyers did not spontaneously address this problem on their own. Rather, the bar was prompted to write this opinion by a Securities and Exchange Commission Release, which threatened to impose an even heavier burden. The SEC Release suggested that lawyers could never rely solely on their client's representations regarding the proposed exceptions to the registration requirements and were required in all cases to pursue their own investigation. The ethics opinion served as a way of forestalling greater external regulation. ${ }^{53}$

In 1982, the bar analyzed lawyers' obligations in giving opinions regarding the

51. See ABA Comm. on Ethics Prof'l Responsibility, Formal Op. 335 (Feb. 2, 1974). This opinion was based on the Model Code of Professional Conduct, the predecessor to the Model Rules of Professional Conduct, which were adopted in 1982. Specifically, the opinion interprets Disciplinary Rule 7-102(A)(5), barring attorneys from making a false statement of material fact in the opinion, and Disciplinary Rule 7-102(A)(7), prohibiting lawyers from knowingly assisting in criminal or fraudulent conduct. This conduct is currently proscribed by Rules 4.1(a) and $1.2(\mathrm{~d})$, respectively.

52. See id.

53. See ABA Comm. on Ethics Prof'l Responsibility, Formal Op. 335, supra note 51, at 1. 
tax consequences of shelters. The ABA concluded that a lawyer violates ethical prohibitions against making a knowingly false statement of law or fact when the lawyer relies solely on his client's assertion of questionable facts in rendering a tax shelter opinion: "The lawyer who accepts as true the facts which the promoter tells him, when the lawyer should know that a further inquiry would disclose that these facts are untrue, also gives a false opinion." ${ }^{, 54}$ As with the opinion regarding unregistered securities, the bar published this opinion in response to a threat of greater government regulation of lawyers' conduct. Here, the U.S. Department of the Treasury had proposed a rule that would have required lawyers to comply with prescribed due diligence requirements before issuing an opinion supporting a tax shelter. ${ }^{55}$

In 2003, after news of the corporate scandals broke, the bar amended Rule 1.13 , which imposes obligations on entity lawyers to report managerial wrongdoing to certain authorities within the organization. The bar was prompted to make these changes by the Sarbanes-Oxley Act legislation, which, among other things, set ethical standards for attorneys appearing before the SEC. ${ }^{56}$ The SEC rules promulgated pursuant to $\S 307$ of the Act require that lawyers report to the chief executive officer or chief legal officer when they have "credible evidence" of wrongdoing. If the managers do not respond appropriately, the lawyer is obligated to report to higher authority within the company. ${ }^{57}$ Model Rule 1.13 was amended in 2003 to impose substantially similar reporting requirements. The reporting requirements in the ethical rules, however, are triggered when a lawyer "knows" that an employee has violated certain legal obligations. Significantly, the comments to this rule were also changed to elaborate on the meaning of knowledge. Thus, comment 3 refers to the definition of knowledge as actual knowledge but adds, "a lawyer cannot ignore the obvious." incorporates the willful ignorance standard in the context of reporting wrongdoing to higher authority within an entity client. It is perhaps not a coincidence that, as with the 1974 opinion regarding legal advice with respect to exceptions to registration requirements and the 1982 opinion on tax shelters, this opinion was written in response to a threat of greater government regulation. The bar

54. ABA Comm. on Ethics Prof'I Responsibility, Formal Op. 346 (1982). The opinion analyzed this issue in the context of Disciplinary Rule 7-102(A)(5), the predecessor of Model Rule 4.1, which forbade a lawyer from making a material misstatement of law or fact, and Disciplinary Rule 1-102(A)(4), the predecessor of Rule 8.4(c), barring "conduct involving dishonesty, fraud, deceit, or misrepresentation." $l d$.

55. Id. at n.2.

56. See Sarbanes-Oxley Act, Pub. L. No. 107-204, 116 Stat. 745 (2002). For a history of Model Rule 1.13 and the Sarbanes-Oxley Act, see STEPHEN GILlers \& RoY D. SIMON, REgUlation OF LAWYERS 173-75 (2007); Roger C. Cramton, George M. Cohen \& Susan P. Koniak, Legal and Ethical Duties of Lawyers After Sarbanes-Oxley, 49 VILL. L. REv. 725 (2004); Susan P. Koniak, When the Hurlyburly's Done: The Bar's Struggle with the SEC, 103 CoLum. L. REv. 1236 (2003); William H. Simon, After Confidentiality: Rethinking the Professional Responsibilities of the Business Lawyer, 75 FORDHAM L. REV. 1453 (2006).

57. 17 C.F.R. $\$ 205$ (2003).

58. Model Rules R. 1.13(b), cmt. 3 (2009). 
expanded the definition of knowledge in the comments to come close to the lower threshold of "credible evidence" in the SEC regulations..$^{59}$

The bar's willingness to alter the definition of knowledge in this context is unsurprising given that Rule 1.13 enforces duties to the client, not duties to third parties. The client is, after all, the entity, and the tension between the duty of confidentiality and the reporting obligation plays no role here. ${ }^{60}$ So reporting up within the entity ought to be a rather uncontroversial aspect of the general duty of loyalty to the client. ${ }^{61}$ Of course, this is not always the case, since the managers exert a great deal of power and are often responsible for deciding which lawyer to hire. ${ }^{62}$ This new comment to Rule 1.13 does nonetheless acknowledge, at least in some circumstances, that it is appropriate to hold lawyers responsible when they deliberately ignore important facts that might trigger difficult or awkward obligations under the ethical rules.

A handful of state ethics cases have similarly cast the lawyer in a more active regulatory role, holding that lawyers cannot simply accept their clients' version of events and must investigate further, at least when the facts seem suspicious. In In re Blatt, for instance, the New Jersey Supreme Court rejected the state ethics committee's recommendation and held that a lawyer committed misconduct by helping a client effect a purchase after failing to investigate its suspicious nature. ${ }^{63}$ The Maryland Supreme Court similarly found that disbarment was appropriate when in-house counsel was convicted for concealing his employer's immigration fraud despite the attorney's assertion that he did not know about the crime. ${ }^{64}$ The attorney claimed that he had never intended to commit the crime and, at most, he had deliberately avoided information that would have led him to

59. See supra note 56 and accompanying text.

60. In fact, Rule 1.13 makes this clear. See Model. Rules R. 1.13(a).

61. Barbara Black, Tattlers and Trailblazers: Attorneys' Liability for Clients' Frauds, 46 WASHBURN L.J. 91, 99-100 (2006).

62. William H. Simon, Introduction: The Post-Enron Identity Crisis of the Business Lawyer, 74 FORDHAM L. REv. 947, 947-50 (2005).

63. 324 A.2d 15, 17-19 (N.J. 1974). The court explained:

A lawyer may not follow the directions of a client without first satisfying himself that the latter is seeking a legitimate and proper goal and intends to employ legal means to attain it. It is no excuse for an attorney to say that he only did what he did because directed to do so by his client. The propriety of any proposed course of action must be initially considered by the attorney, and it may be thereafter pursued only if the lawyer is completely satisfied that it involves no ethical compromise. It is for the lawyer, not the client, to make this decision.

Id. at 18 .

64. See Att'y Grievance Comm'n of Md. v. Wingerter, 929 A.2d 47, $51-56$ (Md. 2007). Wingerter had been convicted in federal court for this conduct so the court relied on Maryland Rule 8.4(b), which states that it is misconduct for an attorney to "commit a criminal act that reflects adversely on the attorney's honesty, trustworthiness, or fitness as a lawyer in other respects," and $8.4(\mathrm{c})$, which bars an attorney from engaging in conduct involving "dishonesty, deceit, or misrepresentation." Id. at 50 n.5. 
know that his employer was engaged in criminal conduct. ${ }^{65}$ In In re Dobson, the South Carolina court also sanctioned an attorney for helping his client while remaining deliberately ignorant of his client's criminal conduct. ${ }^{66}$ The attorney, Robert A. Dobson III, signed a number of blank documents, which his client used to engage in and backdate sham transactions to avoid SEC regulations. ${ }^{67}$ The court found that Dobson had deliberately avoided knowledge that would have implicated him in the fraudulent scheme and stated that the court "will not countenance the conscious avoidance of one's ethical duties as an attorney." 68

In light of historical precedent, it makes more sense to impose a willful ignorance standard on lawyers than on other individuals. The ethical rules of competence and diligence can be read to impose an obligation to know, just as the statutes in the early American cases did. So, according to the historical narrative, as society became more complex and relationships became more deeply entwined and connected to social well-being, the courts acknowledged that individuals can and ought to be responsible for regulating each other. As such, they cannot avoid liability by manufacturing ignorance in the face of certain obvious facts. The legal profession by its position in society and its selfproclaimed rules embodies a private role with clear public responsibility. Arguably, this pre-existing obligation makes it more appropriate to apply the willful ignorance standard to lawyers than to ordinary individuals under the criminal law. The professional is in a position similar to Jewell's (the drug mule who was asked to drive a car full of drugs across the border)-he is critical to the success of the enterprise, but he need not have direct knowledge of its nefarious purpose to play his role. But a lawyer, unlike a drug mule, has some sort of independent legal obligation to know, so his willful blindness ought to be, if anything, more blameworthy.

\section{Professor Luban's Argument AND the ImPaCt ON THE ATTORNEY-CLIENT RELATIONSHIP}

After elegantly exploring the meaning and import of willful ignorance in criminal law, David Luban concludes that lawyers ought to be exempt from this general standard. In other words, he argues, any application of willful ignorance to lawyers' conduct would poison the attorney-client relationship too severely. Professor Luban argues that holding lawyers responsible for consciously avoiding certain facts will turn the lawyer and client into adversaries. According to Luban, clients would intentionally subvert attorneys' investigations of their

65. Id. at 55-56. It is not entirely clear whether the court accepted the idea that Wingerter could be sanctioned when he lacked actual knowledge or assumed that the hearing court rejected this explanation and found that he did, in fact, know about the fraudulent conduct. See id. at 57.

66. See In re Dobson, 427 S.E.2d 166, 166-68 (S.C. 1993).

67. Id.

68. Id. at 168. 
case, knowing that the lawyer is ethically required to find incriminating information, which the lawyer might then be required to turn over. In the process, the client might inadvertently hide innocent facts from the lawyer, which the lawyer needs to represent the client adequately. In sum, the lawyer "may be forced to play a cat-and-mouse game of sleuthing against her own evasive clients." 69

Professor Luban's fear, however, is misguided as a general matter, and in the context of corporate representation, simply inapplicable. There is no reason that a requirement not to avoid obvious and relevant facts should lead an unsuspecting lawyer to investigate any more than he would have otherwise. The requirement would only force attorneys to look further when they encounter obvious signs of wrongdoing. There is no reason to assume that under most circumstances lawyers would be any more cautious than they would have been under the current standard. The rule as written, after all, allows knowledge to be inferred from the circumstances. The only difference would occur when the facts indicate a high probability of wrongdoing and the lawyer declines to investigate nonetheless. In the criminal context, courts have made it clear that a person ought not to be held responsible when he merely fails to make an inquiry upon suspicion, but only when he fails to investigate blatant signs of wrongdoing. ${ }^{70}$ The ethical rules could easily import the same safeguards.

In addition, this argument is based on the unlikely assumption that a client cannot determine what sort of evidence will be helpful to his case but will be able to discern the meaning and import of the confidentiality rules and their exceptions. ${ }^{71}$ It seems far more likely that a client will not understand the full extent of the lawyer's responsibility to report falsehoods or investigate upon clear signs of wrongdoing. If, on the other hand, the client is sophisticated and comprehends the effect of the new definition of knowledge on the lawyer's obligations, the client would most likely also be able to make informed decisions about what information is necessary to ensure the efficacy of the representation. ${ }^{72}$

Underlying Professor Luban's critique of the doctrine is a concern that adding any obligation to investigate, even if it were triggered only by obvious signs of wrongdoing, would irreparably damage the attorney-client relationship. The attorney-client relationship is, however, more resilient than that. Clients have, for instance, adapted to the fact that a lawyer may turn on the client if he knows that the client has lied to the court. ${ }^{73}$ It is not clear why holding lawyers responsible

69. Luban, supra note 9 , at 977.

70. See United States v. Jewell, 532 F.2d 697 (9th Cir.) (en banc), cert. denied, 426 U.S. 951 (1976).

71. See William H. Simon, The Ethics of Criminal Defense, 91 Mich. L. REv. 1703, 1719-21 (1993).

72. Id.

73. Some scholars have argued that there is a limited duty to investigate a client's assertions to avoid putting on perjured testimony. See J. Kevin Quinn et al., Resisting the Individualistic Flavor of Opposition to Model Rule 3.3, 8 GEo. J. Legal Ethics 901, 905-06 (2005) (arguing that Model Rule 1.1 requires some factual investigation into client's assertions to provide competent representation). 
for deliberately ignoring obvious facts would constitute the straw that broke the camel's back rather than just another obligation the lawyer has to the judicial system. ${ }^{74}$

In addition to the relatively minimal damage this requirement would inflict on the attorney-client relationship, it is not clear that the current incentives for lawyers to remain ignorant of perjury or wrongdoing, in fact, help the client. Critics of mandatory disclosure rules have long argued that good representation requires full knowledge. They have suggested that the incentive for lawyers to blind themselves to unpleasant facts, which is at play in the rules as written, distorts a lawyer's understanding of the case and cripples his ability to represent his client adequately. ${ }^{75}$ Thus, it may often be the case that the attorney's deliberate ignorance harms the client, though the client may think otherwise. While proscribing willful ignorance is not the solution these critics seek, it would address the problem they identify in a different way ${ }^{76}$

In rejecting the idea of willful ignorance, Luban relies heavily on examples of defense lawyers who represent individuals accused of a crime. In doing so, Luban implicitly concedes that, like the bar, he too is wedded to the notion that we must have one set of substantive ethical standards for all practicing attorneys. ${ }^{77}$ In the criminal context, because of the inequality in resources and adversarial relationship between government and client, the role of the defense attorney has traditionally been viewed differently. ${ }^{78}$ Arguably, the constitutional right to testify changes the calculus. ${ }^{79}$ Most scholars and attorneys agree that criminal defense lawyers ought to be allowed to take advantage of loopholes, trick their opponents, and stretch the law to its limits to help their clients. The rules, which mean other things in other contexts, are frequently read to permit such conduct. ${ }^{80}$

74. See Fred Zacharias, Lawyers as Gatekeepers, 41 SAN DIEGo L. REv. 1347 (2004) (arguing that lawyers had been acting as gatekeepers long before recent legislative and regulatory proposals).

75. See MonRoe Freedman, Understanding LaWyers' Ethics 109-13 (1990)

76. Rather than creating a right to present false testimony by allowing lawyers to remain ignorant of the truth, critics like Freedman suggest the rules ought directly to permit false testimony, at least in some circumstances. It makes sense to address this issue directly, rather than create the right to testify falsely in a circuitous manner by sanctioning, and even tacitly encouraging lawyers to remain ignorant of the truth. See id.

77. Luban, supra note 9, at 976-80; see also Wilkins, supra note 13, at 1152.

78. See Robert W. Gordon, The Independence of Lawyers, 68 B.U. L. REv. 1, 10-11 (1988).

79. See Crane v. Kentucky, 476 U.S. 683, 690 (1986).

80. See Gordon, supra note 78, at 10-11. In most cases, the rules do not draw explicit distinctions between practice areas. All lawyers are technically required to follow the same rules in the same way. There are a few exceptions. For instance, Model Rule 3.8 directly addresses the role of prosecutors and Model Rule 3.3(a)(3) states that lawyers may refuse to introduce evidence when they "reasonably believe" the evidence is false. However, the rule states that a criminal defense attorney must allow his client to testify unless he "knows" that the evidence is false. Rule 3.1 similarly allows criminal defense lawyers to make some arguments that might be considered frivolous in a civil context. Even when the rules do not make clear distinctions, generally criminal defense lawyers are allowed more latitude in playing with the ethical rules. For instance, conduct that might be considered disruptive in a civil context under Model Rule 3.5(d) would certainly be tolerated by a criminal defense attorney. 
It is not clear, however, that avoiding knowledge that might trigger a reporting obligation or limit the lawyer's ability to call his client to the stand is in fact helpful to criminal defendants. Having a lawyer who investigates and understands all the relevant facts is useful, arguably even essential, to criminal defendants, just as it is for other clients. For that reason, the bar itself has discouraged selective investigation on the part of defense lawyers. ${ }^{81}$ Thus, scholars who emphasize the necessity of the actual knowledge requirement to allow lawyers technically to comply with the ethical rules are misguided. The debate should shift instead to the proper balance between duties to the client and the legal system in the context of criminal cases. If we-can agree that criminal defense attorneys ought to be held to a different standard then the substantive rules regarding perjured testimony ought to be revised to reflect that consensus.

That said, there is no reason to assume that criminal representations are so inherently different, so adversarial, that they categorically resist the imposition of rules designed to protect the judicial system. As the Supreme Court has ruled, the constitutional right to testify is by no means absolute. ${ }^{82}$ Scholars and many practicing attorneys tend to exempt criminal defense lawyers from the critique of overly aggressive and adversarial lawyering. ${ }^{83}$ Professor William Simon argues that this impulse is based on a libertarian understanding of the relationship between the state and the individual. It derives, he suggests, from a fear of totalitarianism - of a state that wields too much power. While this fear is of course compelling, Simon argues that it tends toward such a panic that it outgrows its logic. This kind of libertarianism ignores the concern lurking at the other extreme, which stems from anarchy-a weak state unable to protect its citizens from private harm. The libertarian lawyering rhetoric tends to write both the victims and the public out of the story. In other words, strengthening the individual defendant (regardless of his guilt) at the expense of the state ends up harming other individuals, not simply the abstract entity of government. ${ }^{84}$ Out of concern for these individuals-the public in general and the victims in particular-criminal defendants do not have a right to testify falsely. ${ }^{85}$ Nor do they have a right to their lawyer's assistance in wrongdoing. ${ }^{86}$ As a general matter, the ethical rules' definition of knowledge should not be used surrepti-

81. Standards for Criminal Justice, The Defense Function 4-3.2(b) (1993); see also Standards fOR Criminal Justice, The Defense Function 3.2, cmt. (1970) (warning that advising the client not to admit anything that might make it difficult for the lawyer to call the defendant to the stand is "most egregious" and is advocated only by "unscrupulous" lawyers); STANDARDS FOR CRIMINAL JUSTICE, The Defense Function 4-3.2, cmt. (1993) (describing such conduct as a "flagrant" impropriety).

82. See Nix v. Whiteside, 475 U.S. 157 (1986) (holding that defense counsel's threats to report the defendant if he perjured himself did not constitute ineffective assistance of counsel).

83. See Gordon, supra note 78 , at 11.

84. See Simon, supra note 71 , at 1713.

85. See Model Rules R. 3.3; Nix, 475 U.S. at 169.

86. See Model Rules R. 1.2(d). 
tiously to create those rights. By allowing lawyers to avoid obvious facts that would expose their clients' falsehoods or force them to withdraw from a representation in which their services were being used to commit a crime or fraud, the Rules essentially do just that-manufacture these rights without fully acknowledging their implication.

If, as Professor Monroe Freedman has advocated, the bar concludes that defense lawyers should not have to reveal their clients' perjury, then the rules should say so directly. They should limit the duty to reveal perjury of criminal defendants to situations in which doing so would not interfere with obligations of confidentiality. ${ }^{87}$ Otherwise, the ethical rules use the knowledge requirement to create this substantive reality while obscuring it at the same time. It is hard to see how this subterfuge solves any of the problems. Defense lawyers are subtly being encouraged to do what is otherwise forbidden by the ethical rules. ${ }^{88}$ The rules make it such that they either remain deliberately ignorant of the facts of the case-arguably a violation of the competence rules-or violate the rules regarding perjured testimony. This creates an odd dynamic further alienating defense attorneys from the rest of the bar and making their work seem somehow illicit. Rather than cast criminal defense attorneys as part of a counterculture just a step away from their more unsavory clients, the bar ought to be explicit about their obligations. ${ }^{89}$ Either the rules should allow attorneys to introduce false evidence in this context or they should prohibit it. But permitting them to do so by manufacturing ignorance threatens to interfere with the quality of their representations or simply create a culture of disobedience. ${ }^{90}$

Professor Luban implies that this bit of dissembling is necessary for the system to work and for the participants to feel good about themselves. ${ }^{91}$ It seems to me quite the contrary-the accepted dishonesty inevitably takes a toll on both the system and the individuals involved. Just as living with technical truths that are in fact false or at least misleading undermines an individual's own sense of integrity, the systematic and institutionalized version of this will inevitably erode the legitimacy of the criminal justice system and marginalize defense attorneys. ${ }^{92}$

87. See Monroe H. Freedman, Getting Honest About Client Perjury, 21 Geo. J. Legal Erhics 133, 133-42 (2008).

88. See id. at 142-49. Freedman quotes an ABA ethics opinion, which makes it clear that the knowledge requirement is designed to allow defense lawyers to avoid knowledge of the truth in order to allow their clients to testify falsely. Thus, in the words of ABA Formal Opinion 87-353, it will be "the unusual case" where the lawyer "does know" that a client intends to commit perjury. Knowledge can be established only by the client's "clearly stated intention" to perjure himself at trial. Id. at 142 (quoting ABA Formal Opinion 87-353).

89. See Jed S. Rakoff, How Can You Defend Those Crooks, N.Y. L.J., Sept 25, 1990.

90. In a different context, David Luban has argued that promoting or tolerating unethical conduct in one area can lead to a kind of gerrymandering of all ethical and moral obligations. See LuBAN, supra note 4, at 237.

91. See id. at 229-36.

92. There is a rich psychoanalytic literature on the effect of silence or lies on individuals and the broader social impact of systematized untruths. See, e.g., Sándor Ferenczi, The Confusion of Tongues in Adults and the Child, reprinted in Final Contributions to the Problems and Methods of Psychoanalysis 156 (1955) 
The effort to pretend that criminal defense lawyers abide by the same rules as the rest of the bar does not protect the defense bar. It does not promote effective representations. But it does allow the bar to dodge a difficult issue. It sets the stage for the bar to perpetuate the myth, identified by Professor David Wilkins, "that it is a single profession bound together by unique and specialized norms and practices." ${ }^{.93}$ In fact, the defense bar may need distinct rules and regulations. To recognize this, however, would require the bar to relinquish this foundational belief. By doing so, it would jeopardize the notion that the profession is unified in its ability to transcend profit to preserve the public. ${ }^{94}$ As many scholars have argued, especially in light of the recent financial crisis, perhaps we have to move beyond this paradigm of professionalism. ${ }^{95}$ The vision of a single profession united in its service of the public and its ethical standards may do more harm than good. ${ }^{96}$ Perhaps, this myth constrains creative responses that might help lawyers to adjust to the modern market with all its complex and only partially understood demands. In this context, it makes more sense to insist that all lawyers pay attention to key facts, palatable or not, than to require that all lawyers disclose those facts equally at all times. The former has value in all investigations and representations while the latter seems necessarily to shift depending on the nature of the client and his goals.

Professor Luban elaborates his concern about the deleterious effect of the application of conscious avoidance to lawyers by using the example of the innocent criminal defendant. What happens, he asks, if an innocent client is telling a true story but making up the details? What if that client has already told his partially true story in a court document? In his hypothetical, a diligent but cautious lawyer stumbles on facts that very likely contradict some peripheral aspects of the client's story. Under the proposed regime where he would suffer professional discipline for willfully avoiding the truth, the lawyer would investigate, discover the falsehoods, and would then be forced to retract a largely truthful document to his innocent client's detriment. ${ }^{97}$

This scenario is, on some level, more convincing than general arguments against empowering the state to the detriment of the defendant. Almost everyone

\footnotetext{
(orig. pub. 1932); The Collective Silence: German Identity and the Legacy of Shame (Barbara Heimannsberg \& Christoph J. Schmidt, eds., 1993).

93. Wilkins, supra note 13 , at 1148.

94. See id. at 1148-49.

95. See Ronald J. Gilson, The Devolution of the Legal Profession: A Demand Side Perspective, $49 \mathrm{MD}$. L. Rev. 869 (1990); Russell G. Pearce, The Professionalism Paradigm Shift: Why Discarding Professional Ideology Will Improve the Conduct and Reputation of the Bar, 70 N.Y.U. L. REV. 1229 (1995); Milton C. Regan, Jr., Law Firms, Competition Penalties, and the Value of Professionalism, 13 Geo. J. Legal Ethics 1, 3 (1999). For a discussion of the fate of professionalism after the economic downturn, see Symposium, The Lawyer's Role in a Contemporary Democracy, 77 FordhaM L. REv. 1591 (2009).

96. See Wilkins, supra note 13, at 1216-20; David B. Wilkins, Who Should Regulate Lawyers?, 105 HARV. L. REv. 799, 836-37 (1992).

97. See Luban, supra note 9, at 977.
} 
would agree that we do not want to strengthen the state at the expense of innocent individuals. This concern, however, is more academic than real. First of all, as an empirical matter, it seems an unlikely scenario, And if it really is more common than expected, the rules could add a materiality requirement to the duty to disclose. ${ }^{98}$ Such a requirement already exists for perjury, so the lawyer would not risk exposing his client to criminal penalty. ${ }^{99}$ Alternatively, in his disclosure, the lawyer could make it clear to the court and others that it is only a few details of the story that are off and explain the reason for the discrepancy. As discussed above, the rules should be read in context and should this unlikely scenario come to pass, the authorities could read any of the applicable rules, including the definition of knowledge, to excuse the attorney's failure to report.

Similarly, Professor Luban argues that sometimes, in real life, remaining ignorant of the truth is the right thing to do for the client and for the service of justice. He tells the story of a woman who is seeking political asylum. She recounts that she was a victim of political oppression, raped and tortured in jail and later threatened with death. The lawyer has corroborated all but this last detail. When the lawyer inquires about her brother who now lives in the United States, the client becomes uncomfortable, leaving the lawyer with the impression that the brother has some unfavorable information. Luban claims that the lawyer ought to be allowed to avoid this information by aborting his investigation. ${ }^{100}$ This may be true, just as at times lying to third parties will serve the ends of the client and the ends of justice. Nevertheless, we do not generally allow the exception to demolish the rule. By analogy, it would not make sense to abolish the law against trespass simply because civil rights protestors were justified in breaking this law. ${ }^{101}$ Disciplinary authorities have ample discretion to take the circumstances of the case into account in determining whether to bring an action and what sorts of sanctions to issue, if they choose to do so. ${ }^{102}$ Luban acknowledges as much but then suggests that allowing lawyers to remain ignorant of these unpleasant facts makes it such that they can serve justice without breaking the rules. ${ }^{103}$ True, but Luban's proposed status quo disarms the disciplinary authorities and renders them incapable of punishing those who abuse

98. There is already a materiality requirement in the duty not to make false statements to third parties. See MODEl RuLES R. 4.1(a).

99. See 18 U.S.C. § 1621 (1994).

100. See LUBAN, supra note 4, at 232-36.

101. See William H. Simon, Virtuous Lying: A Critique of Quasi-Categorical Moralism, 12 GEO. J. LEGAL ETHICs 433, 433-35 (1999) (arguing that all ethical rules and moral precepts must be read and interpreted in context and sometimes it makes sense to disregard them).

102. Cf. William H. Simon, Moral Pluck: Legal Ethics in Popular Culture, 101 Colum. L. Rev. 421, 440-47 (2001) (suggesting that ethics rules must be understood and applied not as categorical edicts but rather with careful attention to context and the overall justice of a particular situation); Wilkins, supra note 13, at 1151-60 (arguing that ethical rules are only meaningful in context and regulators regularly rely on context in applying them).

103. See LUBAN, supra note 4, at 234. 
the knowledge requirement to disserve justice.

While the notion of conscious avoidance is relevant when lawyers represent individuals, it comes up most frequently in the corporate context. This is because sophisticated criminal enterprises can and do play with the division of labor and responsibility. They succeed by creating a sum more powerful than the enterprises' parts and they do so, in part, by making sure that no individual and no firm is the repository for all the knowledge or all the wrongdoing. This generates plausible deniability, which protects the individuals along with the enterprise. ${ }^{104}$ Lawyers often contribute to this dynamic by defining their job narrowly. Professor Robert Gordon observed this process, describing a group of corporate lawyers who view themselves as "myopic" or "limited-function bureaucrat[s]" whose representation is confined by the information given to them by the client. $^{105}$

In a preliminary report, the ABA Task Force on Corporate Responsibility, appointed shortly after Enron and other high profile corporate scandals at the beginning of this century, explained that lawyers involved in these frauds "accept[ed] management's instructions and limit[ed] their advice and/or services to a narrowly defined scope, ignoring the context or implications of the advice they [gave]." 106 The preliminary report explained that "[t]here has also been criticism of corporate lawyers for turning a blind eye to the natural consequences of what they observe and claiming that they did not 'know' that the corporate officers they were advising were engaged in misconduct." ${ }^{107}$ The Task Force concluded that, "while lawyers should not be subject to discipline for simple negligence, they should not be permitted to ignore the obvious."108 The preliminary report recommended that the new definition of knowledge ought to apply to provisions barring lawyers from assisting in client crime and lying to third parties, as well as reporting up the ladder within a corporation. ${ }^{109}$ This was obviously a source of controversy, as the final report dropped the suggestion for all provisions except Rule 1.13, the rule requiring reporting illegality to higher authority within a corporate client. ${ }^{110}$

104. See Milton C. Regan, Jr., Professional Responsibility and the Corporate Lawyer, 13 GEO. J. LEGAL Ethics 197, 200 (2000). See generally Kenneth ManN, Defending White-Collar Crime: A Portrait of ATTORNEYS AT WORK (1985).

105. Gordon, supra note 4, at 1193-94.

106. ABA TASK Force on CORPORATE ResponsibILITY, PRELIMINARy REPORT (2002), reprinted in 58 Bus. LAW. 189, 207 (2002) [hereinafter PRELIMINARY REPORT].

107. Id. at 208; see also Gordon, supra note 4, at 1190 (describing a belief among corporate law practitioners that "passive acquiescence" in client fraud and "the failure to inquire or investigate" are consistent with the "highest conceptions of legal, ethical, and professional propriety").

108. Preliminary RePORT, supra note 106, at 208.

109. See id.

110. Am. BAR Ass' N TASK ForCe On CORPORATE RESPONSIBILITY, FinAL REPORT (2003), reprinted in 59 Bus. LAw. 159, 167-70 (2003) [hereinafter FinAL REPORT]. The report is also available at http://www.abanet.org/buslaw/ corporateresponsibility/final_report.pdf. The preliminary report noted that it was meant to serve as "a vehicle to 
The ethical rules were written with individuals in mind. They are, at best, clumsy in their application to business entities. ${ }^{111}$ The knowledge requirement is no exception. Even if it were true that requiring a defense attorney who represents an individual to pursue obvious facts would create an improper balance between the state and the individual, this argument would not apply to business lawyers. In the corporate context, the corporation and the government are far more equal adversaries, with the former outweighing the latter in resources more often than not. More importantly, in most situations they are not quite adversaries. At times, the entity client will be best served by working with regulators to ensure transparency. ${ }^{112}$ The lawyer is in no position to help the client make the critical decision of whether this is so if the lawyer has allowed himself to be diverted from important and relevant facts. As Professor David Wilkins argues, corporate clients are far more powerful market players. They can exert more pressure on lawyers to carry out their immediate wishes. In the corporate context, the Model Rules ought to strengthen the lawyers' commitment to the law and the integrity of the legal system. ${ }^{113}$

The concern about the effect of the conscious avoidance standard on the attorney-client relationship is similarly out of place in the corporate context. The relationship between the lawyer and the authorized representatives of his client is complicated by its very nature. The lawyer has no choice but to interact with his client through its managers, but the lawyer does not represent those individuals. ${ }^{114}$ Given that the corporation's agents might be acting disloyally or at least self-interestedly, the lawyer ought to have some distance from them in order to serve the company as a whole. In representing an organizational client, importing the criminal law standard for knowledge would, if anything, affect the relationship between the lawyer and the agents of the corporation. Because the lawyer does not represent those individuals and the interests of the individuals and the organizational client often diverge, we ought to view this wedge as a positive means to ensure that the lawyer does not rely entirely on the representations of agents as opposed to independently assessing the interests of

elicit comments from interested observers, within the ABA and elsewhere, through a written comment process and one or more public hearings." $1 d$. at 190 . While the final report does not directly address the definition of knowledge in contexts other than Rule 1.13, it does note that commentators at the public hearings argued that lawyers for a corporation are not gatekeepers and are "first and foremost counselors to their clients." Id. at 156.

111. See Regan, supra note 104 , at 199.

112. See Robert W. Gordon, Corporate Law Practice as a Public Calling, 49 MD. L. Rev. 255, 258-59 (1990).

113. See Wilkins, supra note 13 , at 1204-15.

114. See MOdel RULES R. 1.13(a). There are a number of impressive explications of the complications and potential problems inherent in the representation of organizations. See, e.g., Gordon, supra note 78; William H. Simon, After Confidentiality: Rethinking the Professional Responsibilities of the Business Lawyer, 75 FoRDHAM L. REv. 1453 (2006) [hereinafter Simon, After Confidentiality]; William H. Simon, Whom (or What) Does the Organization's Lawyer Represent? An Anatomy of Intraclient Conflict, 91 CAL. L. REv. 57 (2003) [hereinafter Simon, Organization's Lawyer]. 
the entity.

Even if the officers of the corporation would prefer to control the information, in most circumstances the corporation itself will be best served by a lawyer who has full knowledge of its operations. It is hard to imagine how shareholders or the entity in the long run would benefit from a lawyer who is ignorant of his client's actions. If the representation does benefit the client, it is certainly despite the lawyer's ignorance not because of it. Holding lawyers responsible for consciously avoiding relevant facts will help strengthen the lawyer's obligation to his client, as opposed to its representatives. ${ }^{115}$

Acting on behalf of an organizational client rather than one of its many constituents is a difficult task. It is hard to determine when to defer to the managers' judgment and when the managers have conflicts that render them untrustworthy arbiters of the organization's best interest. ${ }^{116}$ There is no hope, however, that an attorney can determine the client's interest (let alone when managers have abandoned it) if the managers are allowed to keep him, with his own complicity, in the dark. In other words, in this context, the underlying purpose of the attorney client privilege- to promote trust so that an attorney can help the client reconcile his own interests with the dictates of the law-cannot possibly be realized unless the lawyer refuses to allow himself to be blinded to unpleasant facts.

Professor Luban argues that forbidding lawyers from remaining oblivious to obvious facts will conscript individuals into paying for lawyers who will serve as their own private investigators. It could force companies to become a financial participant in their own demise. ${ }^{117}$ While superficially appealing, the logic unravels upon further thought. Clients already have to pay for legal services, which include an obligation on the part of attorneys to do things that might hurt the client. For instance, lawyers are not permitted to present false testimony, ${ }^{118}$ and they are required to disclose information if the failure to do so would result in the lawyer participating in a client's wrongdoing. ${ }^{119}$ In the corporate context, this seems particularly unproblematic. Public companies are required to hire outside auditors and at least theoretically, accountants are investigators who have the task of uncovering and reporting information regardless of whether it helps their

115. See generally Gordon, supra note 78; Simon, After Confidentiality, supra note 114; Simon, Organization's Lawyer, supra note 114.

116. See Regan, supra note 104, at 199-200.

117. See Luban, supra note 9 , at 977.

118. MODEl Rules R. 3.3.

119. MODEL RULES R. 4.1(b). I use the example of perjury and client fraud to illustrate the point because these are the most debated and most contested applications of the knowledge requirement. Knowledge does, however, appear as a requirement in other rules, such as Model Rule 4.2, which forbids lawyers from contacting parties whom they "know" are represented by another lawyer. 
client. ${ }^{120}$ As discussed above, while it may indeed hurt some of the agents of the corporation, uncovering wrongdoing in many circumstances will benefit the organizational client in the long run.

A different objection might be articulated as follows: A lawyer who assisted a client in a crime by remaining willfully ignorant of all the relevant facts will still have violated the criminal law. A lawyer who has violated the criminal law will most likely have violated the ethical rules anyway, as Rule 8.4(b) forbids a lawyer from "commit[ting] a criminal act that reflects adversely on the lawyer's honesty, trustworthiness or fitness as a lawyer in other respects." ${ }^{121}$ As a result, it does not really matter whether the knowledge requirement explicitly forbids such conduct.

Combined with the fact that relatively few lawyers are actually disciplined, this is, at least superficially, a persuasive argument. The Model Rules, however, serve a symbolic function. They communicate-albeit in a somewhat conflicted fashion-an ideology of the profession. Professor Richard Abel has argued that the primary function of the rules is to legitimate the profession in the public eye rather than serve as an effective means of regulation. ${ }^{122}$ The current definition of knowledge confirms this thesis. The rules send a message that lawyers must serve the public by protecting the integrity of judicial proceedings and refusing to aid their clients in misconduct. The message borders on empty because, in reality, lawyers can evade these obligations by turning a blind eye to any facts that might trigger them. By explicitly forbidding lawyers from blinding themselves to unpleasant facts, which might ultimately put them in the difficult position of withdrawing, revealing client confidences, or reporting up the ladder, the rules would begin to articulate a definition of the profession more in tune with popular hope, if not expectation. ${ }^{123}$ They would send a message that the role of the lawyer requires more than simply checking off boxes about the legality of facts handed

120. See Securities Act of 1933, 15 U.S.C. $\S 77$ aa (2000) (requiring an independent audit as part of registration statement); Securities Exchange Act of 1934, 15 U.S.C. $\$ 78 \mathrm{~m}$ (a) (2000) (requiring independent audits as part of annual reports); Sarbanes-Oxley Act of 2002, Pub. L. No. 107-204, 116 Stat. 745, $\S 101,105$, 203 (2002) (codified as amended in scattered sections of 11, 15, 18, 28, and 29 U.S.C.) (establishing a board to oversee auditors and setting enforceable standards for auditor independence). Accountants are subject to "GAAS," or generally accepted accounting practices. As scholars have pointed out, however, accountants are only motivated to do what is minimally required by those standards. See, e.g., Peter K.M. Chan, Breaking the Market's Dependence on Independence: An Alternative to the "Independent" Outside Auditor, 9 FORDHAM J. CORP. \& FIN. L. 347, 348 (2004); Jonathan Macey \& Hillary A. Sale, Observations on the Role of Commodification, Independence, and Governance in the Accounting Industry, 48 VILL. L. REV. 1167, 1186-87 (2004).

121. MODEL RULES R. 8.4(b). For an example of a case in which an attorney was disciplined for violating the criminal law by remaining willfully ignorant of his client's criminal conduct, see Att'y Grievance Comm'n of Md. v. Wingerter, 929 A.2d 47 (Md. 2007).

122. See Richard L. Abel, American Lawyers 143 (1991); Richard L. Abel, Why Does the ABA Promulgate Ethical Rules?, 59 TEx. L. REv. 639, 686 (1981).

123. See Colin Croft, Reconceptualizing American Legal Professionalism: A Proposal for Deliberative Moral Community, 67 N.Y.U. L. Rev. 1256 (1992); Lawrence A. Hamermesh, The ABA Task Force on 
to the lawyer by the client.

\section{Attorney LIABILITY IN CRIMINAL, CivIL, AND SEC ENFORCEMENT ACTIONS}

Courts and other regulatory bodies have become increasingly involved in policing lawyer conduct, especially in the context of client fraud. ${ }^{124}$ Unsurprisingly, in both civil and criminal cases, courts generally do not excuse lawyers who help their clients commit crimes but deliberately avoid the illicit nature of their clients' conduct. ${ }^{125}$ As Professor William Simon has argued in a slightly different context, lawyers demonstrate a "visceral clinging to the prerogatives of ignorance and ambiguity," even though the law denies such a shield to their clients. ${ }^{126}$ Not only does this double standard seem inherently unfair and self-interested, it is also confusing. Lawyers are held to a less demanding standard in disciplinary proceedings than in other contexts. Civil, criminal, and regulatory law will generally hold lawyers responsible if they deliberately avoid knowledge of critical facts while the ethical rules do not. Lawyers, brought up on these rules and the culture they create, may not realize that conduct cast as aggressive advocacy could subject them to legal sanctions.

Furthermore, as the bar drags behind other regulators, it runs the risk of rendering itself obsolete. As government entities become more interested in regulating the profession, the bar must send a clear message of its own, rather than lag behind, reacting only defensively to moments of increased regulation.

The application of the willful ignorance standard by courts and government agencies also demonstrates the government's increasing interest in regulating lawyers as part of an industry, rather than as a unitary profession. The fact that the government recognizes distinctions between different sorts of practicing attorneys ought to put some pressure on the bar to begin thinking in a transparent way about these differences.

\section{A. CRIMINAL LAW}

While prosecutors have historically shied away from pursuing lawyers for their part in corporate crime, several prominent cases have begun to undermine

Professional Responsibility and the 2003 Changes to the Model Rules of Professional Conduct, 17 GEO. J. LEGAL ETHICS 35, 56 (2003).

124. See Wilkins, supra note 96, at 807-08; Ted Schneyer, An Interpretation of Recent Developments in the Regulation of Law Practice, 30 OKLA. CITY U. L. REV. 559, 596 (2005).

125. See H. Lowell Brown, The Dilemma of Corporate Counsel Faced with Client Misconduct: Disclosure of Client Confidences or Constructive Discharge, 44 BuFF. L. REv. 777, 777-78 (1996).

126. William Simon makes this argument in the context of the bar's struggle with the Securities and Exchange Commission over the "noisy withdrawal" obligation. William H. Simon, Wrongs of Ignorance and Ambiguity: Lawyer Responsibility for Collective Misconduct, 22 YALE J. ON REG. 1, 30 (2005). 
this convention. ${ }^{127}$ As discussed above, federal criminal law and the law of most states subjects individuals, including lawyers, to punishment if they willfully ignore obvious facts, knowledge of which would otherwise subject them to criminal liability. ${ }^{128}$ In United States $v$. Benjamin, the Court of Appeals for the Second Circuit applied this standard to a lawyer and an accountant who were involved in securities fraud. ${ }^{129}$ In upholding the conviction, Judge Friendly held that "the Government can meet its burden by proving that a defendant deliberately closed his eyes to facts he had a duty to see." ${ }^{130}$ In issuing the opinion, Judge Friendly explained:

In our complex society the accountant's certificate and the lawyer's opinion can be instruments for inflicting pecuniary loss more potent than the chisel or the crowbar. Of course, Congress did not mean that any mistake of law or misstatement of fact should subject an attorney or an accountant to criminal liability simply because more skillful practitioners would not have made them. But Congress equally could not have intended that men holding themselves out as members of these ancient professions should be able to escape criminal liability on a plea of ignorance when they have shut their eyes to what was plainly to be seen or have represented a knowledge they knew they did not possess. ${ }^{131}$

According to Judge Friendly, lawyers, by definition, are required to know certain facts about the representation and cannot escape liability by claiming ignorance.

Despite this precedent, prosecutions of outside counsel for participating in their clients' frauds are rare. The lawyers involved in the Enron transactions, for instance, were never prosecuted. ${ }^{132}$ Nonetheless, prosecutors do periodically indict lawyers for their roles in client fraud. ${ }^{133}$ Recently, Joseph Collins, the head of the derivatives group at Mayer Brown was convicted for assisting in a $\$ 2.4$ billion accounting and securities fraud at Refco. Collins drafted documents that .

127. Some scholars have even suggested that the lawyers who issued opinion letters about torture in the Bush administration ought to be prosecuted. See Claire Finkelstein \& Michael W. Lewis, Should Bush Administration Lawyers Be Prosecuted for Authorizing Torture?, 159 U. PA. L. REv. 195, 195 (2010).

128. See supra notes $15-38$ and accompanying text.

129. See United States v. Benjamin, 328 F.2d 854 (2d Cir. 1964).

130. Id. at 862 .

131. Id. at 863. In a similar case, the Court of Appeals for the Second Circuit upheld the conviction of several lawyers who assisted in a fraud, rejecting the claim that they were merely fulfilling their professional obligations and were unaware of the illegal activity. See United States v. Frank, 494 F.2d 145, 152-53 (2d Cir. 1974). A civil RICO claim for mail or wire fraud can also rest on the allegation that an individual lacked actual knowledge because he deliberately avoided the truth. See Louisiana Power \& Light Co. v. United Gas Line Co., 642 F. Supp. 781, 803 (D. La. 1986).

132. See Michael J. de la Merced, Lawyer for Refco Charged in Fraud, N.Y. Times, Dec. 19, 2007.

133. See id.; Andrew Ross Sorkin, Two Top Tyco Executives Charged With $\$ 600$ Million Fraud Scheme, N.Y. TIMES, Sept. 13, 2002. At times, lawyers are indicted for conduct that the bar might have cast as aggressive advocacy. See Bruce A. Green, The Criminal Regulation of Lawyers, 67 FoRDHAM L. Rev. 327, 355-60 (1998). 
helped the company executives move billions of dollars of debt off the books in a series of sham transactions. Collins failed to convince the jury that the Refco officials kept him in the dark and that his job was not to police the company. ${ }^{134}$

\section{B. CIVIL LIABILITY FOR SECURITIES FRAUD}

The jurisprudence of lawyer liability for securities fraud is somewhat complicated. ${ }^{135}$ In 1994, the Supreme Court held that private plaintiffs could not bring suits for aiding and abetting under section $10 \mathrm{~b}-5$ of the Securities and Exchange Act, which prohibits corporate securities fraud. ${ }^{136}$ After this case, courts have struggled over determining when an individual-including a lawyer-has engaged in the proscribed act, as opposed to accessorial conduct. ${ }^{137}$

Section 10b-5(b) of the Securities and Exchange Act forbids individuals from knowingly making material misrepresentations of fact in connection with the purchase or sale of a security. Some circuits require that the lawyer or firm actually make the misstatement to constitute a violation of the securities laws, while others find it sufficient if the lawyer participated in the preparation of the fraudulent documents. ${ }^{138}$ Lawyers may also be held liable for participating in their clients' fraud under section 10b-5(a) and (c) if they know (or are reckless in not knowing) that their clients' trades are manipulative. ${ }^{139}$

Despite the disagreement over the extent of lawyer liability, courts do hold individuals liable for material misrepresentation under the securities laws if they are reckless in their disregard of the underlying facts. ${ }^{140}$ Thus, an attorney who deliberately deceives himself about his client's criminal conduct. would be considered to have violated the securities laws as long as he met the requirements

134. See Mark Hamblett, Attorney Convicted of 5 Counts in $\$ 2.4$ Billion Federal Fraud, N.Y. L.J., July 13, 2009.

135. See Mark I. Steinberg, The Corporate Securities Attorney as a Moving Target-Client Fraud Dilemmas, 46 WASHBURN L.J. 1 (2006).

136. See Cent. Bank of Denver v. First Interstate Bank of Denver, 511 U.S. 164, 183-91 (1994).

137. See Elizabeth Cosenza, Rethinking Attorney Liability Under 10b-5 in Light of the Supreme Court's Decisions in Tellabs and Stoneridge, 16 GEO. MASON L. REV. 1 (2008).

138. See Barbara Black, Tattlers and Trailblazers: Attorneys' Liability for Client Fraud, 46 WASH. L. REV. 91, 94-95 (2006).

139. See id. at $95-96$.

140. See United States v. Tarallo, 380 F.3d 1174, 1189 (9th Cir. 2004); Southland Secs. Corp. v. Inspire Ins. Solutions, Inc., 365 F.3d 353, 366 (5th Cir. 2004); Ottmann v. Hanger Orthopedic Grp, Inc., 353 F.3d 338, 344 (4th Cir. 2003); Wortley v. Camplin, 333 F.3d 284, 294 (1st Cir. 2003); Kushner v. Beverly Enters., Inc., 317 F.3d 820, 828 (8th Cir. 2003); In re Ikon Office Solutions, Inc., 277 F.3d 658, 672 n.16 (3d Cir. 2002); City of Philadelphia v. Fleming Cos., 264 F.3d 1245, 1258 (10th Cir. 2001); Ziemba v. Cascade Int'l, Inc., 256 F.3d 1194, 1202 (11th Cir. 2001); Suez Equity Investors, L.P. v. Toronto-Dominion Bank, 250 F.3d 87, 99-100 (2d Cir. 2001); Searls v. Glasser, 64 F.3d 1061, 1066 (7th Cir. 1995); Kowal v. MCI Commc'ns Corp., 16 F.3d 1271, 1276 (D.C. Cir. 1994). The Court of Appeals for the Sixth Circuit has equated recklessness with a conscious disregard for the truth. See PR Diamonds, Inc. v. Chandler, 364 F.3d 671, 681 (6th Cir. 2004). 
of primary liability under $10 \mathrm{~b}-5 .{ }^{141}$ In Kline v. First Western Government Securities, Inc., investors relied on a law firm's opinion letters regarding the tax consequences of their investment, which they made through the defendant First Western. When they did not receive the favorable tax consequences, they sued the law firm for negligent misrepresentation. ${ }^{142}$ The Court of Appeals for the Third Circuit found that the law firm could be held liable even though it stated explicitly that it was basing its opinion on the client's representations and did no independent investigation. The court held that an "opinion must not be made with reckless disregard of its falsity or with a lack of genuine belief that the information disclosed was accurate and complete in all material respects." ${ }^{143}$ The court explained that:

When a representation is made by professionals ... there is an obligation to disclose data indicating that the opinion or forecast may be doubtful. When the opinion or forecast is based on underlying materials which on their face or under the circumstances suggest that they cannot be relied on without further inquiry, then the failure to investigate further may support an inference that when the defendant expressed the opinion it had no genuine belief that it had the information on which it could predicate that opinion. ${ }^{144}$

Thus, courts have been less reluctant to hold lawyers to a more robust obligation to the public than the bar. Specifically, case law tends to support some obligation to pursue potentially unfavorable facts.

\section{NEGLIGENCE AND MALPRACTICE}

In some civil contexts, courts also impose a duty on lawyers to investigate their client's representations. Thus, a lawyer who blinds himself to obvious impropriety may well be subject to civil penalty.

In FDIC v. O'Melveny \& Myers, for instance, the receiver of a failed thrift sued

141: See SEC v. Kasirer, No. 04-CV-04340 (N.D. Ill. filed June 29, 2004), Litig. Release No. 19131 (Mar. 11, 2005), available at http://www.sec.gov/litigation/litreleases//r19131.htm. In Kasirer, the SEC alleged that Joel Boehm, an attorney who acted as the underwriter's counsel, issued favorable opinions regarding bond offerings despite his knowledge, or reckless disregard, of the fact that the bond proceeds were being wrongfully commingled and diverted. See Andreo v. Friedlander, 660 F. Supp. 1362, 1366-67 (D. Conn. 1987). Andreo was decided before Central Bank and the attorney was found liable for aiding and abetting his client's fraud. The elements of an aiding and abetting claim include knowledge of the underlying fraud, but the court found that the knowledge requirement could be met if the defendant recklessly disregarded the truth. See id.; see also Abell v. Potomac Ins. Co., 858 F.2d 1104, 1128 (5th Cir. 1988) (finding the evidence insufficient to support liability under the securities laws when the lawyer ignored several red flags that ought to have led him to suspect the propriety of his client's offering because the lawyer was not reckless in doing so).

142. Kline v. First W. Gov't Sec., Inc., 24 F.3d 480 (3d Cir. 1994). At times, disclaimers like the one in Kline will serve to insulate the law firm from liability. See Fortson v. Winstead, 961 F.2d 469, 475 (4th Cir. 1992).

143. Kline, 24 F.3d at 486 (quoting Eisenberg v. Gagnon, 766 F.2d 770, 776 (3d Cir. 1985)) (internal quotation marks omitted).

144. Id. 
the law firm for assisting the thrift in making several private placements when it knew that the thrift had fraudulently overvalued assets and embezzled funds. ${ }^{145}$ To establish knowledge, the suit alleged that the law firm ignored facts that ought to have led it to question the legality of its client's conduct. Lawyers at O'Melveny knew that the auditors and outside law firm had recently resigned, but failed to question the former auditors, law firm, the thrift regulators, or the association's financial officer about the status of its client before issuing opinions and engaging in other work that assisted in procuring investors for the thrift. O'Melveny claimed that it owed no duty to investors to uncover the fraud. The Ninth Circuit held that a law firm cannot rely solely on its client's representations in rendering an opinion in connection with an offering, but must conduct its own investigation. ${ }^{146}$

In FDIC v. Clark, the Tenth Circuit similarly upheld a claim against an outside law firm for failing to investigate signs that its client was involved in misconduct. ${ }^{147}$ The management of a bank had committed a fraud by securing a series of unauthorized loans through the bank. The receiver of the failed bank sued outside counsel for failing to investigate allegations made in a lawsuit that the president had conspired to defraud the bank through these loans. The law firm relied on the president's explanation and did not report the allegations to the board of directors or investigate the claims any further. Relying in part on O'Melveny, the court found that the lawyers were negligent in failing to investigate the allegations. ${ }^{148}$

\section{REGULATORY SANCTIONS}

In addition to civil and criminal liability, courts and the SEC can sanction lawyers for abuses regardless of whether the conduct would constitute a violation under the appropriate ethical rules. ${ }^{149}$ Especially in the context of discovery abuses, courts seem unwilling to excuse lawyers for relying on their clients' representations and turning a blind eye to evidence that might be relevant.

In a recent case, the court sanctioned outside counsel for Qualcomm for failing

145. See FDIC v. O'Melveny \& Myèrs, 969 F.2d 744 (9th Cir. 1992).

146. See id. at 748. The court explained that the firm had no obligation to "ferret out fraud" but did have to make a "reasonable independent investigation." Id. The savings and loan association hired O'Melveny to perform due diligence to confirm the accuracy of statements made in its private placement memoranda. Several courts have distinguished $O^{\prime}$ Melveny by arguing that the lawyers were engaged for more limited purposes. See Black, supra note 138, at 102-03.

147. See FDIC v. Clark, 978 F.2d 1541, 1545-50 (10th Cir. 1992).

148. See id. at 1549-50. Some other courts have taken the opposite position in third party liability cases as opposed to malpractice cases, reasoning that lawyers have no duty to correct misstatements to third parties. So, for instance, the court in Schatz $v$. Rosenberg held that a lawyer for a seller was not liable for forwarding a financial statement he knew to be false to a buyer. See Schatz v. Rosenberg, 943 F.2d 485, 490 (4th Cir. 1991).

149. See FED R. CIV. P. 11, 37, 26(g); Chambers v. NASCO, Inc., 501 U.S. 32, 44-45 (1991) (acknowledging the federal courts' inherent power to manage their courtrooms and cases). 
to search an employee's computer for e-mails responsive to a discovery request. ${ }^{150}$ During the discovery process in a patent infringement suit, attorneys for Qualcomm had information that ought to have led them to suspect that an employee had relevant and responsive information on his computer. The lawyers neglected to search that employee's computer nonetheless. During trial, an associate stumbled upon a relevant e-mail from that employee, which Qualcomm lawyers had not turned over. ${ }^{151}$ The court found that the attorneys

chose not to look in the correct locations for the correct documents, to accept unsubstantiated assurances of an important client that its search was sufficient, to ignore the warning signs that the document search and production were inadequate, not to press Qualcomm employees for the truth, and/or to encourage employees to provide the information ... that Qualcomm needed to ... succeed in the lawsuit. ${ }^{152}$

The court awarded Broadcom attorneys' fees and costs of over eight million dollars and referred Qualcomm's attorneys to the State Bar of California to investigate the potential ethical abuses. ${ }^{153}$

Conduct that might arguably be considered appropriate, aggressive advocacy in the context of legal ethics exposes lawyers to a substantial risk of civil and criminal liability, as well as court sanctions. The disjuncture is confusing to lawyers and sends a message that the organized bar is unconcerned about the impact of its constituents' actions on third parties. This message is damaging to the reputation of lawyers and reinforces the perception that they are unprincipled in their dedication to the interests of their clients without regard to the impact that their clients' actions may have on third parties and the public as a whole.

Again, as courts and other regulatory bodies step in to control the conduct of lawyers, the bar risks its own obsolescence by failing to participate in this endeavor.

\section{Resolving Conflict Between Bodies Regulating Lawyer CONDUCT}

Navigating the world of civil and criminal liability of lawyers can be difficult. Countless scholars have argued without much controversy that the law is unclear and the consequences of conduct uncertain. The law governing lawyers' conduct in these cases, however, does not exist in a vacuum. It interacts in complex ways with the ABA's Model Rules of Professional

150. See Qualcomm Inc. v. Broadcom Corp., No. 05cv1958-B (BLM), 2008 U.S. Dist. LEXIS 911 (S.D. Cal. Jan. 7, 2008).

151. See id. at *6-22.

152. Id. at $* 45$.

153. See id. at *61-64. 
Conduct and state ethical rules. ${ }^{154}$ In the context of securities and other corporate fraud, scholars have argued that the ethical rules have encouraged corporate lawyers to serve as mindless servants to senior managers. ${ }^{155}$ In regard to the definition of knowledge, Susan Koniak has specifically commented that the trigger for the lawyer to act generally occurs when the lawyer "knows" that his client is engaged in fraud. Lawyers, however, are conditioned to believe the managers of their corporate clients so they rarely, if ever, "know" that something illegal has occurred. ${ }^{156}$

Professor Peter Kostant has persuasively suggested that the case law has followed the lead of ethical rules. Prior to the Model Rules of Professional Conduct, the 1908 Canons and the 1970 Model Code recognized that lawyers had a duty to rectify client fraud if the lawyer's services had been used in connection with the conduct, while the Model Rules of Professional Conduct adopted in 1983 abandoned such obligations. ${ }^{157}$ The courts, Kostant argues, have followed suit, reversing their prior understanding that the attorneys cannot escape liability for client fraud by professing ignorance or passivity. ${ }^{158}$ In Schatz v. Rosenberg, a widely cited case, the Fourth Circuit ruled that lawyers, unlike all other agents, can knowingly transmit false information to third parties. ${ }^{159}$ The tides have turned since 1991. The corporate scandals of 2002 and the Sarbanes-Oxley Act have helped to correct and alter the legal landscape but the ethical rules refuse to make this new commitment explicit. As long as they do so, the bar can hide behind client loyalty.

In the past few decades at least, the bar has clung to a vision of lawyers as partisans and advocates for their clients' autonomy. Courts, legislatures, and regulators on the other hand, have to varying degrees grown to expect attorneys to pursue socially useful ends. ${ }^{160}$ In the context of financial fraud, public authorities have periodically required lawyers to help police wrongdoing and secure transparency in the markets. ${ }^{161}$ Given the current financial climate, it seems likely that courts, legislatures, and regulators will demand an even greater partnership from attorneys. By dragging its feet and clinging to the partisan model of lawyering in the face of a contrary trend, the bar risks rendering itself irrelevant, at least in the context of corporate fraud and client

154. Bruce A. Green \& Fred C. Zacharias, Permissive Rules of Professional Conduct, 91 MinN. L. REv. 265, 314-25 (2006).

155. See Peter Kostant, Sarbanes-Oxley and the Changing Norms of Corporate Lawyering, 2004 Mich. ST. L. REv 541, 544 (2004); Gordon, supra note 4, at 1188-90; William H. Simon, The Kaye Scholer Affair: The Lawyer's Duty of Candor and the Bar's Temptations of Evasion and Apology, 23 LAW \& SOC. INQUIRY 243, 264 (1998).

156. Koniak, supra note 56, at 1247.

157. Kostant, supra note 155 , at 546-47.

158. See id. at 547 .

159. See Schatz v. Rosenberg, 943 F.2d 485 (4th Cir. 1991).

160. See Wilkins, supra note 96 , at 863 .

161. See generally GeOFFrey C. HaZARD ET. AL., ThE LAw and Ethics of LAwYERING (4th ed. 2005). 
crimes. One way the ABA can embrace a more complex role for lawyers in the American system is by explicitly forbidding them from avoiding their accepted public function by remaining willfully ignorant of their clients' wrongdoing.

Regulators have historically interpreted the substantive obligations of lawyers differently from the profession. For years, ethics scholars have debated how to approach this divide. In an important article, Professor Susan Koniak argues that this divergence in visions of the substantive obligations of lawyers is evidence that the practicing bar, the courts, and other regulators have different conceptions of the law and different visions of the role of lawyers in the system. ${ }^{162}$ Others have disagreed, arguing the courts are merely elaborating on the inevitable discretion lawyers must bring to bear in particular factual settings. ${ }^{163}$ While this congenial interpretive exchange between the courts and the bar may occur from time to time, the divergence in definitions of knowledge supports Koniak's original position. The disagreement over the proper standards governing lawyers can and does at times reflect a broader disagreement over the meaning of the law and the role lawyers ought to play in society.

Here, courts, legislatures, and administrative agencies are insisting that lawyers act as regulators by refusing to accept their clients' version of events when it is obviously distorted. The legal profession, however, adheres to the partisan approach even if it requires mental contortion to avoid knowledge that might impair zealous advocacy. This produces precisely the kind of normative ambiguity that Koniak describes. ${ }^{164}$ Faced with the conflicting directives and the weak or intermittent commitment of courts, legislatures, and administrative agencies, lawyers will cling to their own vision. ${ }^{165}$ This threatens to expose lawyers to periodic liability as the government chooses to assert its own contrary vision. More importantly, it impairs the deterrent effect of such liability and leaves the public largely unprotected.

Critics of external regulation of the profession argue that the cost to independence is too great. They note that lawyers are supposed to be independent of the state in order to protect citizens from aggressive government intrusion, and argue that allowing the government to regulate lawyers undermines this form of independence. ${ }^{166}$ As David Wilkins and others have pointed out, however, independence is a complex notion. It means

162. See Susan Koniak, The Law Between the Bar and the State, 70 N.C. L. REv. 1389, 1390-92 (1992).

163. See Fred C. Zacharias \& Bruce A. Green, Reconceptualizing Advocacy Ethics, 74 GeO. WASH. L. Rev. 1, 57-59 (2005); Bruce A. Green, The Criminal Regulation of Lawyers, 67 FoRdHAM L. Rev. 327, 330 (1998).

164. See Koniak, supra note 162 , at 1390.

165. See id.

166. See Stephen L. Pepper, The Lawyer's Amoral Ethical Role: A Defense, a Problem, and Some Possibilities, 1986 AM. B. Found. Res. J. 613, 617-19 (1986). 
not only independence from government entities but also independence from clients' whims. Lawyers theoretically ought to have enough distance from their clients (or agents of their client) to resist demands that undermine the law's fundamental purpose or the stability and integrity of the legal framework. ${ }^{167}$ Given the context of most representations, especially in the case of corporate clients, the market incentive is toward a client-centered approach. To protect the integrity of the legal system and the substance of legal commands, the bar ought to defer to other regulatory bodies to balance that incentive with the proper regard for the purposes of the law and the integrity of the legal framework.

The bar's reluctance to embrace the willful ignorance standard offers evidence that the organized bar is committed to its powerful corporate clients while simultaneously being concerned about projecting an image of a public profession committed to communal values. Scholars have long debated the motives of the organized bar. Some argue that the bar, especially the corporate bar, is a tool of its powerful clients and seeks to strengthen the power and prerogative of a corporate elite. ${ }^{168}$ Others suggest that the bar's efforts at law reform are designed to ward off greater regulation. Thus the bar makes gestures at a public function without altering the nature of legal practice. ${ }^{169} \mathrm{In}$ a recent article on the role of tax lawyers, Tanina Rostain argues that the bar is more interested in reinforcing the professional authority of elite tax lawyers than appeasing its clients. ${ }^{170}$ The bar's persistent refusal to adopt a willful ignorance standard, except when reacting to threats of more extensive external regulation, confirms that at least in this instance, the bar is acting to ward off greater regulation by making a nod toward its public function without in fact altering the zealous nature of its constituents' practice. In doing so, it protects powerful clients while simultaneously preserving the image of the profession as devoted to the public interest. While this seems like a cynical interpretation, there is no reason to assume that members of the organized bar are not in fact committed to the image they seek to portray. ${ }^{171}$ The actual knowledge standard, in some ways, allows this contradictory dedication to powerful corporate interests and a public spirit to coexist in an

167. See Wilkins, supra note 96, at 853-72; Gordon, supra note 78, at 13.

168. See Jerold Auerbach, Unequal Justice: Lawyers and Social Change in Modern AMERICA $35-37$ (Oxford University Press) (1976).

169. See Tanina Rostain, Sheltering Lawyers: The Organized Tax Bar and the Tax Shelter Industry, 23 YALE J. ON REG. 77, 80-81 (2006) (describing the various interpretations of bar's motivation).

170. See id.

171. As Professor Rostain points out, many scholars have offered evidence that the bar is in fact dedicated to democratic values and is not entirely self-interested. See id. at $81 \mathrm{n} .13$ (citing TERENCE C. HALLIDAY, BEYOND Monopoly: Lawyers, State Crises, and Professional Empowerment 3 (1987) and Robert W. Gordon, The Ideal and the Actual in the Law: Fantasies and Practices of New York City Lawyers 1870-1910, in THE NEw High Priests: Lawyers in Post-Civil War America 51 (Gerald W. Gawalt ed., 1984)). 
uneasy tension.

The tension, however, breeds a kind of hypocrisy and suppresses a debate over when the client service model ought to give way to other values, at least in the context of certain areas of practice. The actual knowledge standard serves to mask the fundamental disagreement. It papers over the real issues by allowing the profession to articulate and publicly espouse a devotion to communal ends while in reality encouraging lawyers to pursue the interests of their clients without regard to the consequences. If, as scholars like Professor David Wilkins have argued, enforcement proceedings provide a moment to discuss and debate the proper role of lawyers in society, then people on both sides of the debate over the proper role for lawyers ought to embrace that arena. ${ }^{172}$ The knowledge requirement, however, obscures the conflict. For instance, by tacitly encouraging defense lawyers to avoid the truth so as to allow them to put untruthful clients on the stand, the profession has buried the real question about whether we ought to allow lawyers in some contexts to present false evidence.

Because market forces encourage lawyers to capitulate in client demands, the psychological tendency toward deliberate ignorance is even greater than it might otherwise be. ${ }^{173}$ Richard Posner argues that as the demand for lawyers has increased over the course of the last century, the number of lawyers also expanded. The greater demand was met by increased competition amongst lawyers for the prized clients. The competitive market for legal services reinforced the ethical or fiduciary duty toward clients while simultaneously undermining any sense of responsibility to the court or community. ${ }^{174}$ Historians have similarly argued that the nature of practice in the late nineteenth century offered some insulation from market pressures. The increase in corporate clients and the shift in practice from the courtroom to the boardroom similarly affected the public orientation of the profession. ${ }^{175}$ The bar's unwillingness to impose sanctions on lawyers who avoid duties to the public by remaining willfully ignorant of their clients' conduct reinforces this trend.

In addition to allowing the bar to entertain a commitment to public service

172. See Wilkins, supra note 96 , at 884-85.

173. See Richard Posner, Overcoming Law 63-68 (Harvard Univ. Preșs 1995).

174. See id.

175. See Gordon, supra note 171, at 51; Russell G. Pearce, Lawyers as America's Governing Class: The Formation and Dissolution of the Original Understanding of the Lawyer's Role, 8 U. CHI. L. SCH. ROUNDTABLE 381,397 (2001). Gordon, among others, expresses skepticism about what is known as the "declension thesis"-the idea that the legal profession has declined from a golden moment in the past in which lawyers were truly dedicated to a public purpose to its current state of total devotion to clients' selfish goals. See Gordon, supra note 78, at 48-68; Norman W. Spaulding, The Myth of Civil Republicanism: Interrogating the Ideology of Antebellum Legal Ethics, 71 FordHAM L. REV. 1397, 1398-1400 (2003). At the same time, they recognize that the myth of decline is based on some factual reality. See Gordon, supra note 78, at 51. 
while tacitly allowing it to erode in practice, the bar's continuous fight with the government over lawyer regulation might take a different form were the bar forced to acknowledge the increasingly relevant distinctions between different sorts of practicing lawyers. The bar might be more willing to revisit the proper relationship between client loyalty and service to the public and legal system in discrete contexts.

\section{CONCLUSION}

There are no compelling reasons to treat lawyers with greater leniency than other individuals under the criminal law. In crafting a definition of knowledge under criminal law, courts and scholars had to grapple with due process concerns. We do put people in prison for remaining willfully ignorant of certain facts. Given that the stakes are so much lower and the concerns more prosaic, the disciplinary rules should not employ a more limited definition of knowledge. It is hard to know at the outset of a representation whether ignoring obvious facts will actually benefit or harm the client. The rules should work to discourage such deliberate ignorance. Doing so will help harmonize the rules protecting the public, third parties, and the integrity of the justice system with rules regarding privilege and confidentiality. It will help strengthen the positive and socially beneficial aspects of the attorneyclient relationship while, at least theoretically, discouraging the destructive manipulation of the lawyer's role.

The notion that lawyers will no longer be able to close their eyes to obvious signs of wrongdoing will also strengthen the role of the business lawyer. It will help clarify his obligations to the managers or representatives of his client and the client itself. While it is a difficult, often impossible, task to determine the best interests of a corporate client, the business lawyer must do so, at times, without substituting the opinion of the managers for that of the organization. In order to determine when the managers are no longer trustworthy and to make the difficult calculation of the client's interest, a lawyer needs full information. There is no hope for making this calculation if the lawyer has blinded himself to important facts. Thus, proscribing willful ignorance is critical not only to help prevent lawyers from becoming pawns in a corporate fraud but also to ensure that lawyers are serving the client as a whole rather than merely the sometimes distorted view of its current representatives.

As Professor Luban has pointed out, there may be serious repercussions of a willful ignorance standard for criminal defense lawyers. Defense attorneys rely on the actual knowledge standard to put their clients on the stand even when their testimony is highly doubtful. There are two responses to this concern. First, perhaps it would be good to revisit the question of how tolerant we ought to be of perjury when it comes from a criminal defendant. Forcing 
lawyers to pursue suspicious facts may well trigger a more direct and productive conversation over the proper role of criminal defense lawyers in this regard. Second, the rules have been read to apply differently in different contexts. Criminal defense attorneys are frequently treated differently. There is no reason why this rule couldn't be applied with equal sensitivity to context.

The bar has consistently relied on different applications of the actual knowledge standard to make real distinctions between different sorts of lawyers engaged in different sorts of practice. By doing so, it can maintain one set of substantive standards that seemingly apply equally to all lawyers. Thus, the use of actual knowledge not only stifles a debate on the proper role of lawyers in a democratic system, it also perpetuates a myth that there is one profession. In addition to bringing the debate over the proper balance between client loyalty and public service to the surface, adopting a willful ignorance standard might force the bar to revisit its assumption that there is one profession subject to one set of uniform standards. 